\title{
Calcium carbonate corrosivity in an Alaskan inland sea
}

\author{
W. Evans ${ }^{1,2}$, J. T. Mathis ${ }^{1,2}$, and J. N. Cross ${ }^{1,2}$ \\ ${ }^{1}$ Ocean Acidification Research Center, School of Fisheries and Ocean Sciences, University of Alaska Fairbanks, Fairbanks, \\ Alaska, USA \\ ${ }^{2}$ National Oceanic and Atmospheric Administration, Pacific Marine Environmental Laboratory, Seattle, Washington, USA \\ Correspondence to: W. Evans (wiley.evans@noaa.gov)
}

Received: 26 August 2013 - Published in Biogeosciences Discuss.: 10 September 2013

Revised: 4 December 2013 - Accepted: 18 December 2013 - Published: 28 January 2014

\begin{abstract}
Ocean acidification is the hydrogen ion increase caused by the oceanic uptake of anthropogenic $\mathrm{CO}_{2}$, and is a focal point in marine biogeochemistry, in part, because this chemical reaction reduces calcium carbonate $\left(\mathrm{CaCO}_{3}\right)$ saturation states $(\Omega)$ to levels that are corrosive (i.e., $\Omega \leq$ 1) to shell-forming marine organisms. However, other processes can drive $\mathrm{CaCO}_{3}$ corrosivity; specifically, the addition of tidewater glacial melt. Carbonate system data collected in May and September from 2009 through 2012 in Prince William Sound (PWS), a semienclosed inland sea located on the south-central coast of Alaska and ringed with fjords containing tidewater glaciers, reveal the unique impact of glacial melt on $\mathrm{CaCO}_{3}$ corrosivity. Initial limited sampling was expanded in September 2011 to span large portions of the western and central sound, and included two fjords proximal to tidewater glaciers: Icy Bay and Columbia Bay. The observed conditions in these fjords affected $\mathrm{CaCO}_{3}$ corrosivity in the upper water column $(<50 \mathrm{~m})$ in PWS in two ways: (1) as spring-time formation sites of mode water with near-corrosive $\Omega$ levels seen below the mixed layer over a portion of the sound, and (2) as point sources for surface plumes of glacial melt with corrosive $\Omega$ levels ( $\Omega$ for aragonite and calcite down to 0.60 and 1.02 , respectively) and carbon dioxide partial pressures $\left(p \mathrm{CO}_{2}\right)$ well below atmospheric levels. $\mathrm{CaCO}_{3}$ corrosivity in glacial melt plumes is poorly reflected by $p \mathrm{CO}_{2}$ or $\mathrm{pH}_{\mathrm{T}}$, indicating that either one of these carbonate parameters alone would fail to track $\Omega$ in PWS. The unique $\Omega$ and $p \mathrm{CO}_{2}$ conditions in the glacial melt plumes enhances atmospheric $\mathrm{CO}_{2}$ uptake, which, if not offset by mixing or primary productivity, would rapidly exacerbate $\mathrm{CaCO}_{3}$ corrosivity in a positive feedback. The cumulative effects of glacial melt and air-sea gas exchange are likely responsible for the seasonal reduction of $\Omega$ in PWS,
\end{abstract}

making PWS highly sensitive to increasing atmospheric $\mathrm{CO}_{2}$ and amplified $\mathrm{CaCO}_{3}$ corrosivity.

\section{Introduction}

The uptake of anthropogenic carbon dioxide $\left(\mathrm{CO}_{2}\right)$ by the contemporary ocean increases the concentration of hydrogen ions (lowers seawater $\mathrm{pH}$ ), which drives a cascade of alterations in the marine carbonate system in a phenomenon known as ocean acidification (OA) (Gattuso and Hansson, 2011; Doney et al., 2009; Caldeira and Wickett, 2003; Raven et al., 2005; Orr et al., 2005; Dore et al., 2009). Of particular biogeochemical importance, raising hydrogen ion concentrations consume carbonate ions $\left(\mathrm{CO}_{3}^{2-}\right)$, which in turn reduces the saturation state $(\Omega)$ of calcium carbonate $\left(\mathrm{CaCO}_{3}\right)$ minerals important for shell-forming marine organisms (Fabry et al., 2008; Feely et al., 2004, 2009; Millero, 2007). When $\Omega$, defined as the ion product of $\mathrm{CO}_{3}^{2-}$ and calcium $\left(\mathrm{Ca}^{2+}\right)$ in seawater relative to the stoichiometric solubility product for $\mathrm{CaCO}_{3}$ at a given temperature, salinity and pressure, is reduced to levels below 1, waters become corrosive to $\mathrm{CaCO}_{3}$ and dissolution occurs. Two major phases of $\mathrm{CaCO}_{3}$, aragonite and calcite, have specific solubility products that cause aragonite to be $\sim 1.5$ times more soluble than calcite (Dickson, 2010), such that aragonite becomes undersaturated and dissolves before calcite in the ocean (Orr et al., 2005). Corrosive $\Omega$ levels for both phases of $\mathrm{CaCO}_{3}$ are naturally found in the ocean at depths below the level of continental shelves (Millero, 2007). However, ocean acidification as a direct response to rising atmospheric $\mathrm{CO}_{2}$ is causing these levels to shoal above the depth of the shelf break $(\sim 200 \mathrm{~m})$ and inundate shallow water in some coastal locations (Bryne et al., 
2010; Bates et al., 2009; Feely et al., 2008, 2010; Leinweber and Gruber, 2013; Mathis et al., 2011a, b, 2014b) making these areas vulnerable to environmental changes with an associated disruption in ecosystem services (Cooley and Doney, 2009; Barton et al., 2012; Feely et al., 2012; Mathis et al., 2014a). In many of these locations, natural variability in the carbonate system and/or coastal eutrophication can combine synergistically with OA to drive manifestations of severe $\mathrm{CaCO}_{3}$ corrosivity (Harris et al., 2013a; Cai et al., 2011; Mathis et al., 2011b). However, independent of OA, $\mathrm{CaCO}_{3}$ corrosivity can result from processes such as the influence of coastal rivers (Salisbury et al., 2008; Tank et al., 2012) and sea ice melt in high latitude settings (YamamotoKawaii et al., 2009, 2013; Chierici and Fransson, 2009; Bates et al., 2009; Azetsu-Scott et al., 2010). To date, $\mathrm{CaCO}_{3}$ corrosivity from glacial discharge has received far less attention.

Glacial discharge to the marine environment may occur directly from marine-terminating tidewater glaciers or via proglacial (immediately in front of a glacier) streams draining mountain-terminating glaciers. The discharge at oceanglacier interfaces has unique chemical characteristics free from additional alteration that would occur in proglacial streams. That is, glacial water in streams can receive added alkalinity through the dissolution of carbonate sediments and/or vegetation processes (Anderson et al., 2000). Depending on the flow path of meltwater through a glacier, there may be less chance for interaction with bedrock and sediments. Therefore, meltwater transmitted directly to the coastal ocean will have a lower alkalinity than stream-transmitted glacial meltwater. Glacial discharge from tidewater glaciers takes the form of melt plumes in adjacent, proglacial coastal waters, and are created by a mixture of subglacial discharge, melt from the glacier ice face, and melting calved ice (Motyka et al., 2003). Subglacial discharge occurs at the grounding line of the glacier or at some other submarine level, and can account for a high percentage ( $>50 \%$ ) of the discharge from tidewater glaciers (Motyka et al., 2003; Walters et al., 1988; Mortensen et al., 2013). Subglacial discharge creates a region of turbulent convective flow immediately adjacent to the terminus of tidewater glaciers where mixing from rising buoyant melt plumes enhances melt from the glacier ice face, undercutting the glacier terminus and accelerating the calving rate (Motyka et al., 2003; Ritchie et al., 2008). The combination of these processes creates glacial melt plumes in proximal coastal waters with distinct temperature and salinity characteristics (Motyka et al., 2003; Walters et al., 1988; Mortensen et al., 2013).

Glacial melt plumes are expected to be biogeochemically unique, however, this has been underrepresented in the literature. Studies have focused on the impact of glacial melt from the standpoint of contributing to freshwater runoff (Neal et al., 2010), sea level rise (Arendt et al., 2002; Larsen et al., 2007; Gardner et al., 2013; Berthier et al., 2010), as a source of labile organic matter (Hood et al., 2009), as a source of stratification and/or turbidity that influences coastal pri- mary productivity and carbon uptake (Dierssen et al., 2002; Shadwick et al., 2013), and as a source of the micronutrient iron (Bhatia et al., 2013). To date, only two studies have described the impact of glacial melt on the marine carbonate system. Both of these studies report undersaturated $\mathrm{CO}_{2}$ partial pressures $\left(p \mathrm{CO}_{2}\right)$ with respect to the atmosphere in Greenland coastal surface waters impacted by glacial melt (Rysgaard et al., 2012b; Sejr et al., 2011). Sejr et al. (2011) observed a high sediment load in low- $p \mathrm{CO}_{2}$ runoff from proglacial rivers in Young Sound on the northeast coast of Greenland, and a more than $100 \mu \mathrm{atm}$ difference between directly measured $p \mathrm{CO}_{2}$ and $p \mathrm{CO}_{2}$ calculated from dissolved inorganic carbon (DIC) and total alkalinity (TA). The difference in $p \mathrm{CO}_{2}$ was correlated with turbidity, with the largest disparity coinciding with instances of highest sediment load. The explanation invoked by Sejr et al. (2011) was that, due to the reactive nature of carbonate particles in glacial meltwater (Brown, 2002), these particles reacted chemically either during storage or analysis of the DIC / TA samples and added approximately 7 to $10 \%$ more alkalinity, which then resulted in lower $p \mathrm{CO}_{2}$ than what was directly observed. Sejr et al. (2011) then hypothesized that the reactive particles in low- $p \mathrm{CO}_{2}$ glacial melt consumed additional $\mathrm{CO}_{2}$ and contributed to the widespread low surface $p \mathrm{CO}_{2}$ seen throughout Young Sound. Rysgaard et al. (2012) reported similar results from Godthåbsfjord on the southwestern coast of Greenland, where the occurrence of high TA relative to DIC in undersaturated surface water with respect to atmospheric $\mathrm{CO}_{2}$ was used to argue the importance of glacial discharge that contained reactive carbonate minerals for setting air-sea $\mathrm{CO}_{2}$ uptake.

A concurrent increase in TA and decrease in $p \mathrm{CO}_{2}$ in the surface water impacted by glacial discharge that contained reactive carbonate minerals would also imply an increase in $\Omega$ levels. Therefore, glacial discharge that is less buffered by the presence of reactive particles derived from proglacial river sediments should have lower, more corrosive, $\Omega$ levels, and this may co-occur with undersaturated $p \mathrm{CO}_{2}$. A situation can then exist where surface waters corrosive to $\mathrm{CaCO}_{3}$ may become more corrosive by the uptake of atmospheric $\mathrm{CO}_{2}$. Here, we present data from Prince William Sound (PWS), an Alaskan inland sea ringed with tidewater glaciers (Fig. 1), which provide evidence that glacial discharge in this high latitude coastal setting has a radical impact on the corrosivity of $\mathrm{CaCO}_{3}$ that may then be exacerbated by air-sea gas exchange.

\section{Study area}

PWS is a semienclosed, sub-Arctic inland sea on the southcentral coast of Alaska that exchanges with the adjacent Gulf of Alaska (GOA) largely via two passages: Hinchinbrook Entrance and Montague Strait (Fig. 1). It is defined as an inland sea because appreciable horizontal circulation occurs in the 


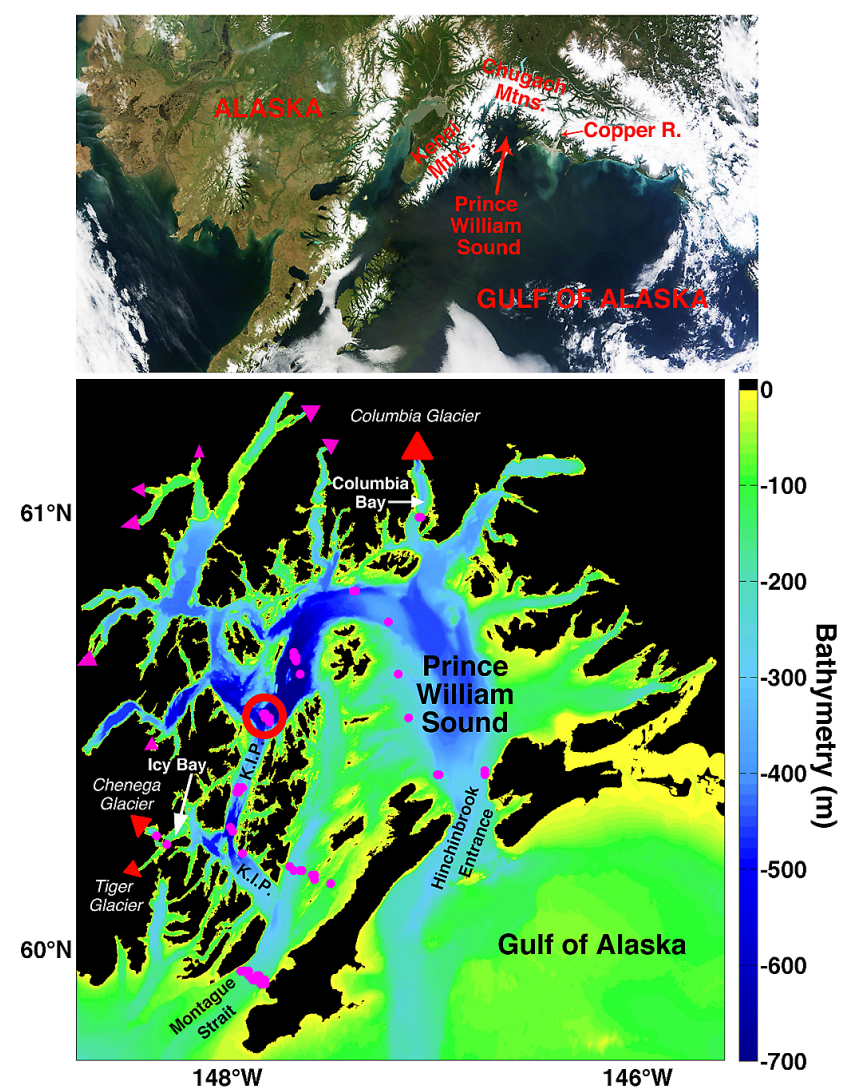

Fig. 1. Top panel is a Moderate Resolution Imaging Spectroradiometer (MODIS) true color image of southern Alaska from spectral data collected aboard the National Aeronautics and Space Administration (NASA) Terra satellite on 16 June 2013. The image was provided by the NASA Earth Observatory (http://earthobservatory.nasa.gov/IOTD/view.php?id= 81416/\&src=eoa-iotd), and shows a cloud-free day over southern Alaska with Prince William Sound (PWS) and the adjacent Gulf of Alaska (GOA) visible from space. Labeled geological features relevant to this study are the Chugach and Kenai mountain ranges on the north and west side of PWS, respectively, and the Copper River. Lower panel is bathymetry (color bar; $\mathrm{m}$ ) of PWS with the locations of hydro-casts marked where dissolved inorganic carbon (DIC) and total alkalinity (TA) measurements were collected (magenta dots). Hinchinbrook Entrance and Montague Strait are labeled, as these are the major connections between PWS and the GOA. Knight Island Passage (K.I.P.) is the north-south oriented channel in the western portion of PWS. Icy Bay and Columbia Bay are marked because these fjords were sampled for the reason that they contain tidewater glaciers. The glaciers in these fjords are marked by red triangles, and other tidewater glaciers in PWS are marked by magenta triangles. Bathymetry data are from a digital elevation model (DEM) provided by the National Oceanic and Atmospheric Administration (NOAA) National Geophysical Data Center (NGDC; http://www.ngdc.noaa.gov/mgg/coastal/). The red circle delineates the single station (PWS2) that was sampled during every survey of PWS from 2009 through 2012. surface layer (Niebauer et al., 1994; Musgrave et al., 2013; Halverson et al., 2012b; Vaughan et al., 2001). Downwellingfavorable winds, which dominate from September through May, drive surface flow into PWS through Hinchinbrook Entrance, with compensatory outflow through Montague Strait (Niebauer et al., 1994; Halverson et al., 2012a). This "flowthrough" scenario is reduced and more complex between May and September, when winds are only weakly downwelling favorable or upwelling favorable and surface flows are typically weaker with reversals through either strait becoming more common (Halverson et al., 2012a; Niebauer et al., 1994). However, transport at this time can be highly baroclinic, with inflow at depth flushing the deepest portions of PWS (>400 m) in as fast as a month (Halverson et al., 2012a). The central region of PWS is a deep $400 \mathrm{~m}$ basin, which is silled from the adjacent GOA at a depth of approximately $250 \mathrm{~m}$ at Hinchinbrook Entrance and near $150 \mathrm{~m}$ at Montague Strait (Fig. 1). The central region is defined as the area north of Hinchinbrook Entrance, and is approximately $50 \mathrm{~km}$ wide. A shoal with a series of islands separates the western and central regions of PWS, and the main northsouth channel the in western PWS is Knight Island Passage (K.I.P.; Fig. 1). Near the northern terminus of K.I.P. is the deepest area in PWS, with depths reaching approximately $700 \mathrm{~m}$. Surrounding PWS are the Chugach and Kenai mountain ranges to the north and west, respectively, which reach to heights approaching $4 \mathrm{~km}$. These mountain ranges contain extensive ice fields and glaciers, many of which are losing volume rapidly due to climate change (Arendt et al., 2002, 2006). Encircling PWS from Columbia Bay westward are numerous proglacial fjords with tidewater glaciers originating from these mountains (Fig. 1). Glacial discharge, either as a direct input to the sound or indirectly via proglacial streams, contributes an estimated $60 \%$ of the freshwater discharged to PWS, which itself contributes $11 \%$ of the total runoff to the GOA (Neal et al., 2010). The large freshwater supply to PWS, coupled with the fact that the adjacent GOA shelf is shallower than significant portions of the sound, also makes this inland sea a complex fjord-type estuary.

\section{Data collection and analysis}

Beginning in 2009, bi-annual carbonate system measurements were collected within PWS during May and September as part of a broader carbonate system study on the GOA continental margin (Mathis et al., 2014b; Evans and Mathis, 2013; Evans et al., 2013b). Data were collected aboard the US Fish and Wildlife Service R/V Tiglax. Hydrographic data and seawater samples were collected from select depths at stations in PWS using a rosette equipped with $5 \mathrm{~L}$ Niskin bottles and a Sea-Bird 911Plus conductivity-temperature-depth (CTD) profiler. Temperature $(T)$ and salinity $(S$; calculated from conductivity) data presented here were processed using standard protocols recommended by Seabird, and salinity 
data are reported in this manuscript using the Practical Salinity Scale (PSS-78, dimensionless). DIC and TA samples were drawn from Niskin bottles into clean $250 \mathrm{~mL}$ Pyrex glass reagent bottles using established gas sampling protocols (Dickson et al., 2007). The Pyrex bottles were pretreated with $200 \mu \mathrm{L}$ of saturated $\mathrm{HgCl}_{2}$ solution to prohibit biological alteration, and a headspace of $<1 \%$ of the bottle volume was left to allow for water expansion. Fixed samples were sealed and analyzed for DIC and TA at the University of Alaska (UAF) Ocean Acidification Research Center (OARC) using a VINDTA 3C (http://www.marianda.com/index.php? site $=$ products $\backslash \&$ subsite $=$ vindta3c). Seawater certified reference materials (prepared by A. G. Dickson, Scripps Institute of Oceanography) were analyzed before samples were processed to ensure that DIC and TA measurements were accurate to within $0.1 \%(\sim 2 \mu \mathrm{mol} \mathrm{kg}-1)$. Dissolved oxygen $\left(\mathrm{O}_{2}\right)$ samples were drawn from the Niskin bottles prior to DIC and TA sampling, and processed using a modified version of the Winkler titration method (Langdon, 2010). Dissolved $\mathrm{O}_{2}$ values are presented here as $\Delta \mathrm{O}_{2}$, which represent the dissolved seawater concentration $\left(\mu \mathrm{mol} \mathrm{kg}{ }^{-1}\right)$ minus the $\mathrm{O}_{2}$ saturation concentration $\left(\mu \mathrm{mol} \mathrm{kg}{ }^{-1}\right)$ at the in situ temperature and salinity. The $\mathrm{O}_{2}$ saturation concentrations were calculated using the equations described by García and Gordon (1992). Nutrient samples were drawn from Niskin bottles into $20 \mathrm{~mL}$ Nalgene high density polyethylene scintillation vials, frozen at sea and processed at UAF using an Alpkem Rapid Flow Analyzer 300 and protocols following Whitledge et al. (1981). The nominal precision and accuracy of the silicate and phosphate measurements were $<0.1 \mu \mathrm{mol} \mathrm{kg}-1$. The saturation state of aragonite $\left(\Omega_{\mathrm{arag}}\right)$ and calcite $\left(\Omega_{\text {calc }}\right)$ phases of $\mathrm{CaCO}_{3}$ were calculated using the T, S, pressure, DIC, TA, silicate and phosphate data with the constants described by Lueker et al. (2000) via a Matlab version of CO2SYS (van Heuven et al., 2011). The Lueker et al. (2000) constants were chosen because they are applicable to measurements over the range of $T$ and $S$ values observed in PWS. With these constants, $\mathrm{pH}$ is calculated on the total hydrogen ion scale $\left(\mathrm{pH}_{\mathrm{T}}\right)$.

\section{Results and discussion}

A total of 8 cruises surveyed PWS between 2009 and 2012 during May and September (Fig. 1). The first 5 cruises conducted a limited number of stations within Montague Strait and K.I.P. in western PWS. The three latter cruises in this data set, first occurring in September 2011, had expanded coverage over western and central portions of PWS, during which $56 \%$ of the 744 carbonate system measurements were collected. One station, located near the northern terminus of K.I.P, was sampled during all 8 cruises (circled station in Fig. 1). During September 2011, water column carbonate chemistry was sampled for the first time at a station in Icy Bay adjacent to the Chenega Glacier (within $1 \mathrm{~km}$; Fig. 1). The following May, a station was occupied in Columbia Bay abutting the moraine shoal of Columbia Glacier. The depth of the moraine shoal ranges between near sea level to $\sim 20 \mathrm{~m}$, and it acts as a barrier to ship travel because it is populated with grounded icebergs produced by the calving face of Columbia Glacier. The terminus of Columbia Glacier was approximately $20 \mathrm{~km}$ north of the moraine shoal at the time the survey was conducted (http://earthobservatory.nasa.gov/Features/ WorldOfChange/columbia_glacier.php). In September 2012 both near-glacier sites were repeated, however our approach to Chenega Glacier in Icy Bay was limited by extensive calved ice. General patterns immediately evident in the PWS data set were that (1) variability in all parameters was greatest at the surface $(<9 \mathrm{~m})$ compared with that seen at depth $(>500 \mathrm{~m}$ ), and (2) there was a significant increase in the dynamic range of surface $T, S$, TA, DIC, $\Omega_{\text {arag }}$ and $\Omega_{\text {calc }}$ in September relative to May, which was not reflected in $p \mathrm{CO}_{2}$ or $\mathrm{pH}_{\mathrm{T}}$ (Table 1).

\subsection{Trends in PWS carbonate data}

The trends in TA versus salinity for the entire PWS data set revealed a large excursion from a linear fit at low salinities (Fig. 2). Extrapolation of this linear fit to zero salinity would imply a freshwater TA end-member of $648 \mu \mathrm{mol} \mathrm{kg}-1$; however, the low salinity data suggest a much lower freshwater TA end-member. DIC data followed this depletion in TA at low salinities, albeit the ratio of TA to DIC declined (Fig. 2). The TA/DIC ratio provides a means for identifying instances of DIC addition or removal relative to TA; and when TA and DIC are close to 1 , the concentration of $\mathrm{CO}_{3}^{2-}$ is low (Chierici and Fransson, 2009; Sarmiento and Gruber, 2006). Figure 2 shows a decrease in the TA / DIC ratio at both high and low salinities, with surface water $(<9 \mathrm{~m})$ having a TA / DIC ratio of less than 1.06 at low salinity (Fig. 2). Mean deep water $(>500 \mathrm{~m})$ TA and DIC were not largely different between May and September, with concentrations near 2220 and 2160, respectively (Table 1). The lowest TA/DIC ratios were in this water with values of 1.01 (Table 1). The high DIC relative to TA in deep water was presumed to result from the remineralization of organic matter that was produced in the euphotic zone and delivered to depth, and from the seasonal exchange of deep water with the adjacent GOA (Niebauer et al., 1994) that has a low TA/DIC ratio (Mathis and Evans, unpublished data, 2013).

$\mathrm{pH}_{\mathrm{T}}, \Omega_{\mathrm{arag}}$, and $p \mathrm{CO}_{2}$ became decoupled in low salinity surface water that had concurrent low TA/DIC ratios (Fig. 3). These carbonate parameters are tightly coupled in deep water, with corrosive levels of $\Omega_{\text {arag }}$ (i.e., $<1$ ) coinciding with values of $\mathrm{pH}_{\mathrm{T}}$ below 7.87 and $p \mathrm{CO}_{2}$ above $565 \mu \mathrm{atm}$ (Fig. 3). $\mathrm{pH}_{\mathrm{T}}, \Omega_{\mathrm{arag}}$, and $p \mathrm{CO}_{2}$ are also tightly coupled between salinities of 24 and 32, as instances of high TA/DIC ratio $(>1.1)$, which correspond to surface $(<9 \mathrm{~m})$ measurements (Table 1), coincided with the highest values of $\Omega_{\text {arag }}$ 

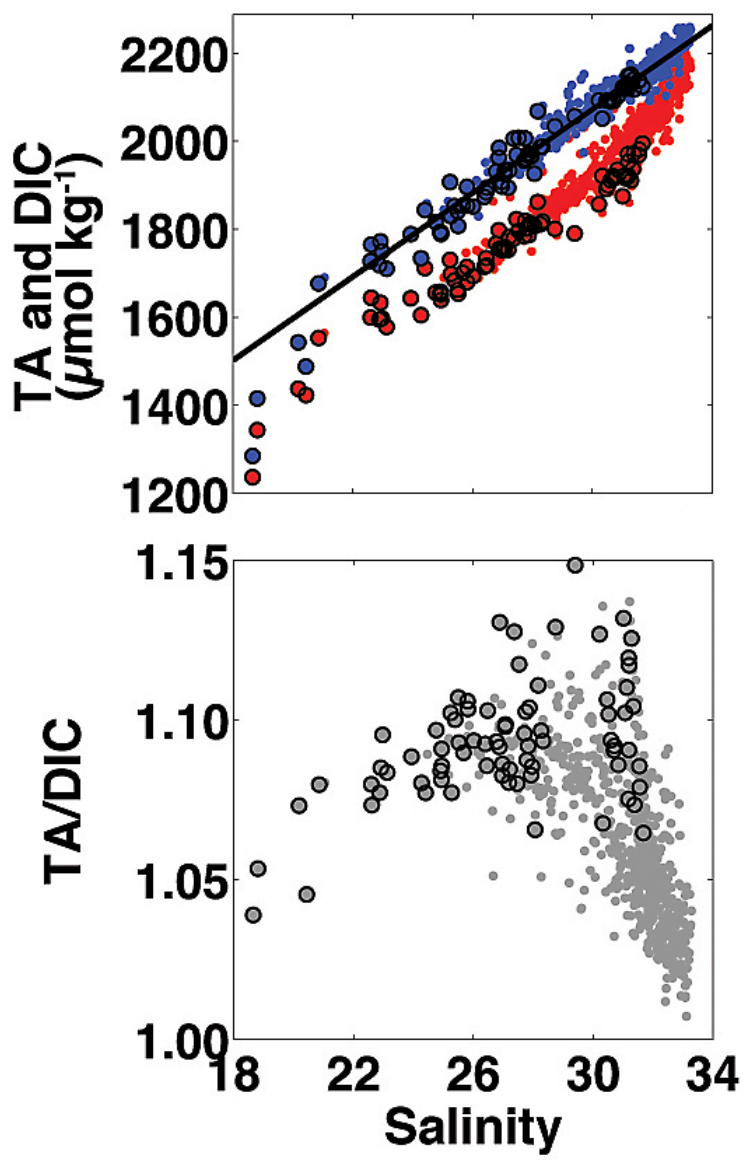

Fig. 2. May and September PWS measurements of TA (blue) and DIC (red) collected between 2009 and 2012 as a function of salinity (top; $\mu \mathrm{mol} \mathrm{kg}{ }^{-1}$ ). A linear fit between TA and salinity is shown for data with salinity greater than $22\left(\mathrm{TA}=47.5 \times\right.$ Salinity $+648 ; r^{2}=$ 0.96). Lower panel shows TA/DIC ratio versus salinity. Surface data $(<9 \mathrm{~m})$ are highlighted in each panel using bold circles.

and $\mathrm{pH}_{\mathrm{T}}$, and $p \mathrm{CO}_{2}$ well below saturation with respect to the atmosphere (Fig. 3). The instances of high TA / DIC ratio corresponded with positive $\Delta \mathrm{O}_{2}$ values and depleted nitrate $\left(\mathrm{NO}_{3}^{-}\right)$concentrations (Fig. 4). Concurrent observations of $\mathrm{O}_{2}$ oversaturations, depleted $\mathrm{NO}_{3}^{-}$concentrations and drawn down DIC levels provide strong evidence of episodes of high primary productivity. Positive $\Delta \mathrm{O}_{2}$ values in the face of rapid air-sea gas exchange could have only resulted from high rates of primary production. In both of the above situations, $\Omega_{\text {arag }}$ and $\mathrm{pH}_{\mathrm{T}}$ tracked each other while $p \mathrm{CO}_{2}$ had an inverse trend (Fig. 3). These relationships between the three variables are typical of the manifestations of $\mathrm{CaCO}_{3}$ corrosivity in coastal settings (Feely et al., 2008; Harris et al., 2013b; Cai et al., 2011; Leinweber and Gruber, 2013; Mathis et al., 2014c). The relationships between $\Omega_{\mathrm{arag}}, \mathrm{pH}_{\mathrm{T}}$ and $p \mathrm{CO}_{2}$ changed at salinities less than 24 in this setting (Fig. 3). In these low-salinity surface waters, TA fell below the typical mixing line with freshwater and the TA/DIC ra-
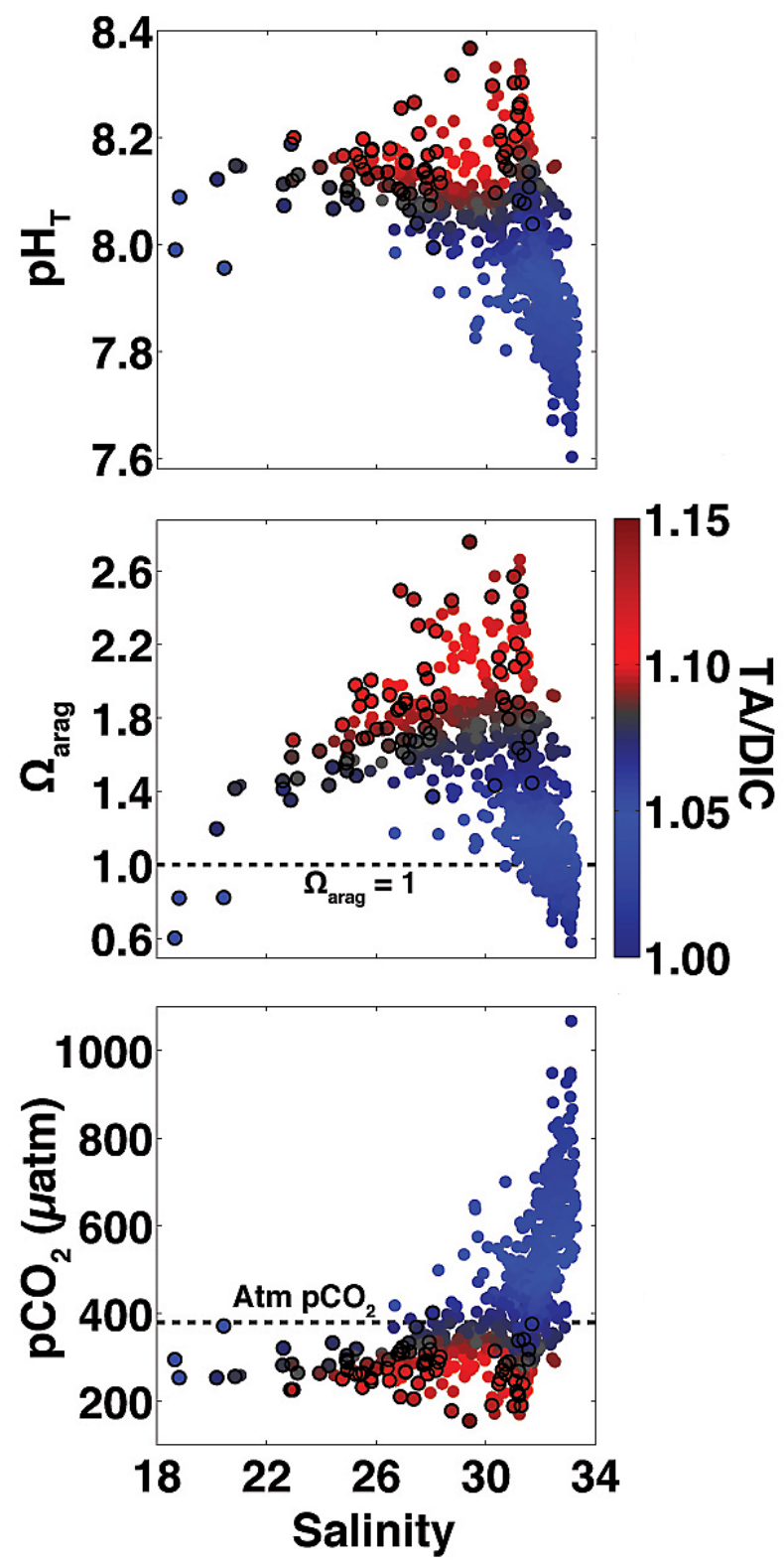

Fig. 3. $\mathrm{pH}_{\mathrm{T}}$ (top), $\Omega_{\mathrm{arag}}$ (middle), and $\mathrm{pCO}_{2}$ (bottom; $\mu$ atm) as a function of salinity and TA / DIC ratio. The dashed horizontal line in the middle panel is the $\Omega_{\text {arag }}=1$ level below which dissolution of aragonite will occur, and the dashed horizontal line in the lower panel is the September 2012 atmospheric $p \mathrm{CO}_{2}$ in PWS estimated following Evans and Mathis (2013; $380 \mu \mathrm{atm})$. Surface data $(<9 \mathrm{~m})$ are highlighted in each panel using bold circles.

tio approached the low levels seen in PWS deep basin water (Table 1, Fig. 2). Corrosive levels of $\Omega_{\text {arag }}$ at the lowest salinities were similar to those seen at the highest salinities in deep water, however, $p \mathrm{CO}_{2}$ was undersaturated with respect to the atmosphere while $\mathrm{pH}_{\mathrm{T}}$ was not as low as the values observed at depth (Fig. 3). 
Table 1. Mean $(\mu)$, standard deviation $(\sigma)$, minimum and maximum values of $T, S$, TA $\left(\mu \mathrm{mol} \mathrm{kg}^{-1}\right), \mathrm{DIC}(\mu \mathrm{mol} \mathrm{kg}-1)$, TA $/ \mathrm{DIC}, p \mathrm{CO} 2$ ( $\mu \mathrm{atm}), \mathrm{pH}_{\mathrm{T}}, \Omega_{\mathrm{arag}}$ and $\Omega_{\text {calc }}$ for surface $(<9 \mathrm{~m})$ and deep $(>500 \mathrm{~m})$ samples collected in PWS in May and September. The total number of measurements for each parameter was 744; the number of May surface and deep data was 25 and 7, respectively; the number of September surface and deep data was 54 and 20, respectively.

\begin{tabular}{|c|c|c|c|c|c|c|c|c|c|c|c|c|c|c|c|c|c|c|}
\hline & \multicolumn{2}{|c|}{$T$} & \multicolumn{2}{|c|}{$S$} & \multicolumn{2}{|c|}{$\mathrm{TA}$} & \multicolumn{2}{|c|}{ DIC } & \multicolumn{2}{|c|}{ TA / DIC } & \multicolumn{2}{|c|}{$p \mathrm{CO}_{2}$} & \multicolumn{2}{|c|}{$\mathrm{pH}_{\mathrm{T}}$} & \multicolumn{2}{|c|}{$\Omega_{\text {arag }}$} & \multicolumn{2}{|c|}{$\Omega_{\text {calc }}$} \\
\hline & $\mu$ & $\sigma$ & $\mu$ & $\sigma$ & $\mu$ & $\sigma$ & $\mu$ & $\sigma$ & $\mu$ & $\sigma$ & $\mu$ & $\sigma$ & $\mu$ & $\sigma$ & $\mu$ & $\sigma$ & $\mu$ & $\sigma$ \\
\hline $\begin{array}{l}\text { May } \\
<9 \text { m }\end{array}$ & 6.1 & 1.0 & 30.9 & 0.7 & 2111.8 & 31.7 & 1916.8 & 50.3 & 1.10 & 0.02 & 254 & 59 & 8.20 & 0.09 & 2.07 & 0.38 & 3.30 & 0.61 \\
\hline $\begin{array}{l}\text { May } \\
>500 \mathrm{~m}\end{array}$ & 5.4 & 0.1 & 32.9 & 0.2 & 2222.3 & 15.7 & 2158.8 & 23.0 & 1.03 & 0.01 & 724 & 168 & 7.77 & 0.09 & 0.86 & 0.16 & 1.35 & 0.25 \\
\hline $\begin{array}{l}\text { September } \\
<9 \mathrm{~m}\end{array}$ & 11.5 & 1.5 & 25.5 & 2.5 & 1845.5 & 150.5 & 1693.3 & 122.8 & 1.09 & 0.02 & 284 & 39 & 8.12 & 0.06 & 1.69 & 0.35 & 2.73 & 0.54 \\
\hline \multirow[t]{2}{*}{$\begin{array}{l}\text { September } \\
>500 \mathrm{~m}\end{array}$} & 5.4 & 0.2 & 33.1 & 0.1 & 2224.6 & 24.9 & 2156.8 & 28.8 & 1.03 & 0.01 & 695 & 114 & 7.79 & 0.07 & 0.88 & 0.13 & 1.39 & 0.20 \\
\hline & $\min$ & $\max$ & $\min$ & $\max$ & $\min$ & $\max$ & $\min$ & $\max$ & $\min$ & $\max$ & $\min$ & $\max$ & $\min$ & $\max$ & $\min$ & $\max$ & $\min$ & $\max$ \\
\hline $\begin{array}{l}\text { May } \\
<9 \text { m }\end{array}$ & 3.2 & 7.4 & 28.7 & 31.7 & 2033.6 & 2151.0 & 1790.4 & 1995.0 & 1.06 & 1.15 & 155 & 376 & 8.04 & 8.37 & 1.43 & 2.76 & 2.30 & 4.41 \\
\hline $\begin{array}{l}\text { May } \\
>500 \mathrm{~m}\end{array}$ & 5.3 & 5.6 & 32.8 & 33.1 & 2212.1 & 2257.0 & 2135.0 & 2198.0 & 1.01 & 1.04 & 602 & 1067 & 7.60 & 7.85 & 0.58 & 1.03 & 0.91 & 1.63 \\
\hline $\begin{array}{l}\text { September } \\
<9 \mathrm{~m}\end{array}$ & 6.1 & 13.3 & 18.7 & 28.3 & 1285.2 & 2068.2 & 1237.0 & 1861.7 & 1.04 & 1.13 & 205 & 401 & 7.96 & 8.27 & 0.60 & 2.49 & 1.02 & 3.99 \\
\hline $\begin{array}{l}\text { September } \\
>500 \mathrm{~m}\end{array}$ & 5.2 & 5.6 & 32.9 & 33.3 & 2154.8 & 2258.3 & 2095.7 & 2200.5 & 1.01 & 1.05 & 529 & 948 & 7.65 & 7.90 & 0.65 & 1.10 & 1.02 & 1.74 \\
\hline
\end{tabular}

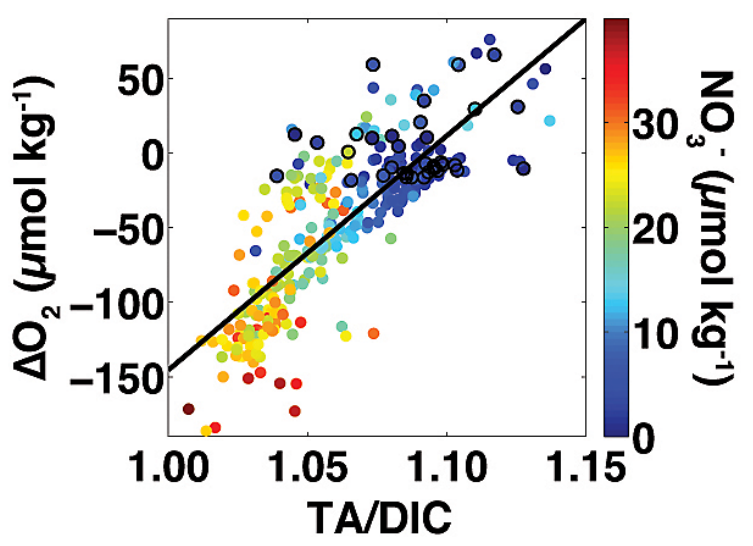

Fig. 4. Measured $\mathrm{O}_{2}$ minus the saturation $\mathrm{O}_{2}$ value $\left(\Delta \mathrm{O}_{2}\right.$; $\mu \mathrm{mol} \mathrm{kg}-1)$ as a function of TA/DIC ratio and $\mathrm{NO}_{3}^{-}$concentration $\left(\mu \mathrm{mol} \mathrm{kg}{ }^{-1}\right)$. A linear fit between $\Delta \mathrm{O}_{2}$ and TA/DIC ratio is shown $\left(\Delta \mathrm{O}_{2}=1569 \times \mathrm{TA} / \mathrm{DIC}+-1714 ; r^{2}=0.65\right)$. Surface data $(<9 \mathrm{~m})$ are highlighted using bold circles.

The decoupling between $\mathrm{CaCO}_{3}$ corrosivity and $p \mathrm{CO}_{2}$ or $\mathrm{pH}_{\mathrm{T}}$ in PWS surface water appeared in September but not May. May $\Omega_{\text {arag }}$ data followed a predictable relationship with $p \mathrm{CO}_{2}$ that was well represented by a polynomial fit (Fig. 5). High $p \mathrm{CO}_{2}$ levels coincided with low and corrosive $\Omega_{\text {arag }}$ values, and lowest $p \mathrm{CO}_{2}$ corresponded with highest $\Omega_{\text {arag }}$. The lowest $p \mathrm{CO}_{2}$ and highest $\Omega_{\text {arag }}$ conditions were seen at this time. The relationship between $\Omega_{\text {arag }}$ and $p \mathrm{CO}_{2}$ was far less predictable for September data. September data, in general, followed a different trajectory than the May data,
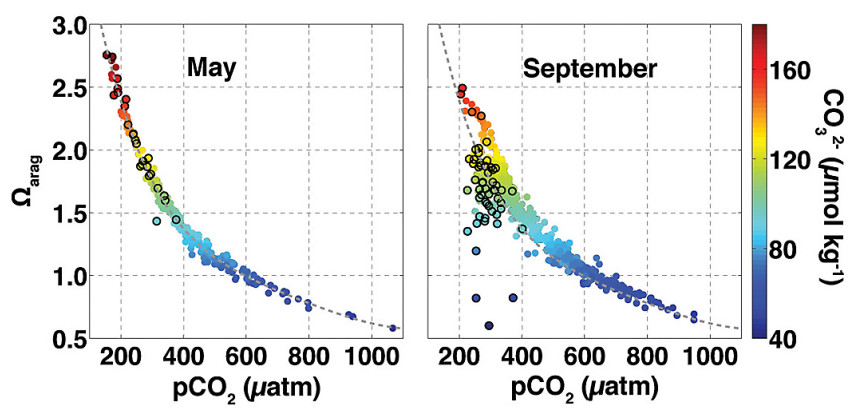

Fig. 5. May (left) and September (right) $\Omega_{\text {arag }}$ as a function of $p \mathrm{CO}_{2}(\mu \mathrm{atm})$ and $\mathrm{CO}_{3}^{2-}\left(\mu \mathrm{mol} \mathrm{kg}{ }^{-1}\right)$. The dashed gray line is a 5 th order polynomial fit to the May data. Surface data $(<9 \mathrm{~m})$ are highlighted in each panel using bold circles.

being mostly above the May polynomial fit at $p \mathrm{CO}_{2}$ values less than $600 \mu \mathrm{atm}$, and with a large degree of scatter at a $p \mathrm{CO}_{2}$ range between 200 and $400 \mu$ atm (Fig. 5). September data falling above the May fit with high $p \mathrm{CO}_{2}$ for a given $\Omega_{\text {arag }}$ were likely the result of the seasonal surface warming seen in PWS between May and September, as the observed mean $5{ }^{\circ} \mathrm{C}$ temperature increase would drive a $60 \mu \mathrm{atm}$ increase in $p \mathrm{CO}_{2}$ but only a 0.05 unit increase in $\Omega_{\text {arag }}$ relative to the spring mean surface values (Table 1). The largest variability in $\Omega_{\text {arag }}$ at a given $p \mathrm{CO}_{2}$ in the September data coincided with surface measurements with depleted $\mathrm{CO}_{3}^{2-}$ concentrations by as much as $100 \mu \mathrm{mol} \mathrm{kg}^{-1}$ (Fig. 5). The lowest $\Omega_{\text {arag }}$ value observed (0.6) was one of the low- $p \mathrm{CO}_{2}$, low- $\mathrm{CO}_{3}^{2-}$ data points, and was seen in low salinity surface 
water depleted in TA (Figs. 2, 3); these characteristics were found in data collected near tidewater glaciers (Figs. 1, 6).

\subsection{Near glacier observations}

During each September occupation of a station proximal to Chenega Glacier in Icy Bay (Fig. 1), cold, lowsalinity surface water was observed with undersaturated $p \mathrm{CO}_{2}$ and $\Omega_{\text {arag }}$ (Fig. 6). These low salinity surface plumes, which span between 10 and $20 \mathrm{~m}$, are diluted in TA, and have low TA/DIC ratios making them depleted in $\mathrm{CO}_{3}^{2-}$. These surface plumes had low, nonzero $\mathrm{NO}_{3}^{-}$concentrations ranging from 2 to $8 \mu \mathrm{mol} \mathrm{kg}{ }^{-1}$, and $\Delta \mathrm{O}_{2}$ ranging from $-40 \mu \mathrm{mol} \mathrm{kg}{ }^{-1}$ to near saturation with the atmosphere (Fig. 6). The first observation of surface near-corrosive calcite saturations in the GOA was at this site and under these conditions (Fig. 6). However, our data reveal that there is appreciable variability in the surface expressions of $\mathrm{CaCO}_{3}$ corrosivity in glacial melt plumes. A consistent feature of the water column in and around Icy Bay at this time of year was a mid-depth temperature maximum caused by the cold surface melt plume overriding warmer water from the adjacent main basin in the western PWS (Gay III and Vaughan, 2001). During 2011 , the temperature of this layer was $\sim 3{ }^{\circ} \mathrm{C}$ warmer than it was in 2012; $\Omega_{\mathrm{arag}}$ in this layer, and at the surface, was nearly 0.3 units higher in 2011 than in 2012 (Fig. 6).

To evaluate the source waters responsible for these characteristics, we calculated mixing lines, following Walters et al. (1988), between (1) PWS source waters in the mid-depth temperature maximum and freshwater at $0^{\circ} \mathrm{C}$ (Fig. 7; "mixing line"), and (2) PWS source water and water from glacial melt (Fig. 7; "melt-line"). When ice, either at or calved from the glacier terminus, melts in seawater, latent heat of fusion causes a relatively large change in temperature per unit salinity. This trait has been used to distinguish glacial melt from other sources of freshwater in Columbia Bay (Walters et al., 1988) and in some Greenland fjords (Mortensen et al., 2013). The larger change in temperature per unit salinity results in a steeper "melt line" from adding glacial melt compared with the "mixing line" from freshwater addition. Note that subglacial discharge alone would simply be a source of freshwater, albeit does not typically occur alone in summer but rather in conjunction with melting from the glacier ice face that then enhances the calving rate from the glacier (Ritchie et al., 2008; Motyka et al., 2003). As such, glacial melt plumes at this time of year would be a combination of these three constituents of glacial melt. $T / S$ data collected during 2012 track the "melt line" indicated strong modification by glacial melt, with only a small region of departure in the very near surface layer (Figs. 6, 7). The data from 2011 follow a nearconsistent trajectory between the "mixing line" and the "melt line", indicating only moderate modification by glacial melt relative to the 2012 data (Fig. 7). We suggest that the more corrosive conditions observed in 2012 were due to the greater addition of glacial melt relative to 2011. Ancillary evidence that the degree of glacial melt in Icy Bay was greater in 2012 is that our approach was limited to at least $3 \mathrm{~km}$ from the terminus of Chenega Glacier (Fig. 1) by the high density of calved ice, but the most corrosive conditions to date were observed then. In 2011 we were able to get much closer to the glacier terminus yet the water column was less corrosive to $\mathrm{CaCO}_{3}$ (Fig. 6)

Data from Icy Bay illustrated that there are year-to-year differences in glacial melt and the degree of $\mathrm{CaCO}_{3}$ corrosivity, but data from Columbia Bay show that there is a critical seasonal difference that has implications for corrosivity over the upper water column in PWS. In May and September 2012, a station near the moraine shoal of Columbia Bay (Fig. 1) was sampled for carbonate chemistry. Profiles revealed vastly different conditions between these months in this fjord (Fig. 8). During September, the mid-depth temperature maximum indicative of the adjacent PWS basin water was present, as well as a cold, low-salinity surface melt plume with $\Omega_{\text {arag }}$ levels less than those seen at mid-depth. Although there are differences between these September data, and those from Icy Bay (Fig. 6), the patterns are consistent between the two fjords and reflect the varying degree of corrosivity in surface melt plume water. Conversely, in May there was essentially no plume. Vertical profiles of $T$ and $S$ show nearly homogenous conditions with very little evidence of stratification (Fig. 8). Temperatures cooled considerably from depth to the surface, where only a slight decrease in salinity was observed. $\Omega_{\text {arag }}$ at this time varied by only \pm 0.1 units, being near-corrosive with values close to 1.2 throughout the water column (Fig. 8). At adjacent stations, we identified a water mass at $40 \mathrm{~m}$ that appeared to extend from Columbia Bay across a large portion of the western PWS (Fig. 9). This mode water had specific $T$ and $S$, and therefore potential density anomaly $\left(\sigma_{t}\right)$ characteristics, and was below the mixed layer based on the World Ocean Circulation Experiment mixed layer depth criterion of a $0.125 \mathrm{~kg} \mathrm{~m}^{-3}$ change from the surface $\sigma_{t}$ value (Monterey and Levitus, 1997). This water mass could also be identified by mid-depth temperature minima in the broader PWS (Fig. 9), and such cold layers have been previously observed in association with proglacial fjords (Gay III and Vaughan, 2001; Pickard, 1967).

We suggest that Columbia Bay, and likely other proglacial fjords in and around PWS, serve as mode water formation sites near the end of winter when surface water temperatures are at their coolest. Glacial melt at this time is typically at a minimum because subglacial discharge is reduced and proximal fjord water temperatures are cooler (Motyka et al., 2003), however, for the case of Columbia Glacier, which has been retreating catastrophically (Post et al., 2011), the proximal fjord is likely still impacted by melt sources from the glacier that then can affect water properties on the seaward side of the moraine shoal in Columbia Bay. Thus, at its formation site, this mode water may be imprinted with chemical signals from glacial melt. In this way mid-layers of the water column may be impacted by corrosive mode water formed in 

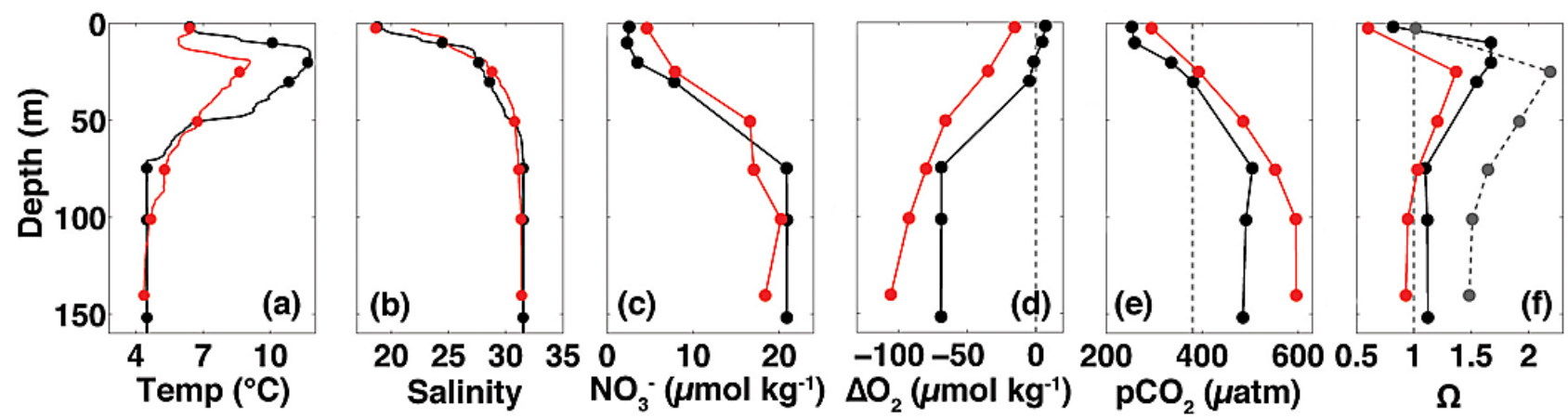

Fig. 6. Depth profiles from Icy Bay (Fig. 1) collected during September in 2011 (black) and 2012 (red) of temperature (a; ${ }^{\circ} \mathrm{C}$ ), salinity (b), $\mathrm{NO}_{3}^{-}\left(\mathbf{c} ; \mu \mathrm{mol} \mathrm{kg}{ }^{-1}\right), \Delta \mathrm{O}_{2}\left(\mathbf{d} ; \mu \mathrm{mol} \mathrm{kg}{ }^{-1}\right), p \mathrm{CO}_{2}(\mathbf{e} ; \mu \mathrm{atm})$, and $\Omega(\mathbf{f})$. Temperature and salinity traces are from CTD downcasts, and dots are the measurements made at the depth Niskin bottles were fired during upcasts. The gray dashed line in panel (d) denotes $\Delta \mathrm{O}_{2}$ in equilibrium with the atmosphere. The gray dashed line in (e) is the atmospheric $p \mathrm{CO}_{2}$ for September 2012 in PWS from Evans and Mathis (2013). The gray vertical line in (f) is the $\Omega=1$ level below which $\mathrm{CaCO}_{3}$ dissolution will occur. (f) Shows $\Omega_{\text {arag }}$ for September 2011 (black), and both $\Omega_{\text {arag }}$ (red) and $\Omega_{\text {calc }}$ (gray) from September 2012; nearly corrosive surface levels of $\Omega_{\text {calc }}(1.02)$ were seen here for the first time in the GOA.

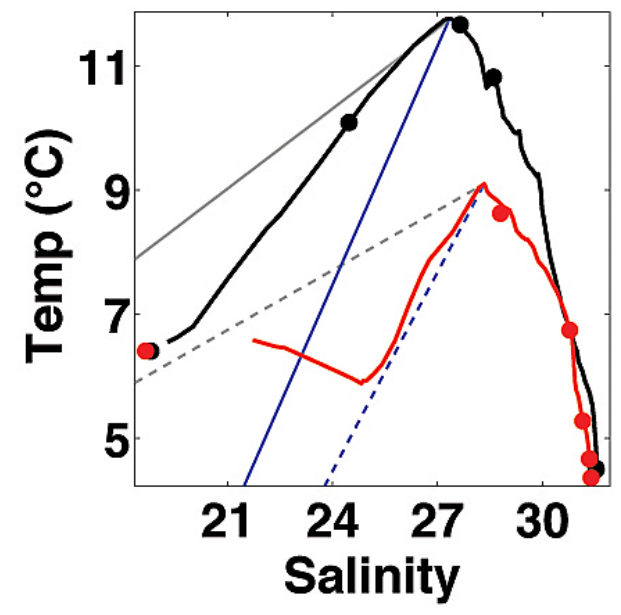

Fig. 7. Temperature $\left({ }^{\circ} \mathrm{C}\right)$-salinity diagram for September 2011 (black) and September 2012 (red) profiles in Icy Bay (Fig. 1). Traces are from CTD downcasts, and dots are the measurements made at the depth Niskin bottles were fired during upcasts. The solid and dashed gray lines are mixing lines between source waters estimated from Fig. 6, and freshwater at $0{ }^{\circ} \mathrm{C}$, with solid and dashed lines marking 2011 and 2012 data, respectively. The solid and dashed blue lines are mixing lines that describe ice melting in seawater, following Walters et al. (1988), with the 2011 and 2012 source water characteristics, respectively.

proglacial fjords, while the surface water column during this time period serves as a refuge from $\mathrm{CaCO}_{3}$ corrosivity.

\subsection{Far-field influence of glacial melt}

Data collected at PWS2, the station north of K.I.P. that has been repeated during every cruise in PWS (Fig. 1), revealed that springtime temperature minima occur every year. The
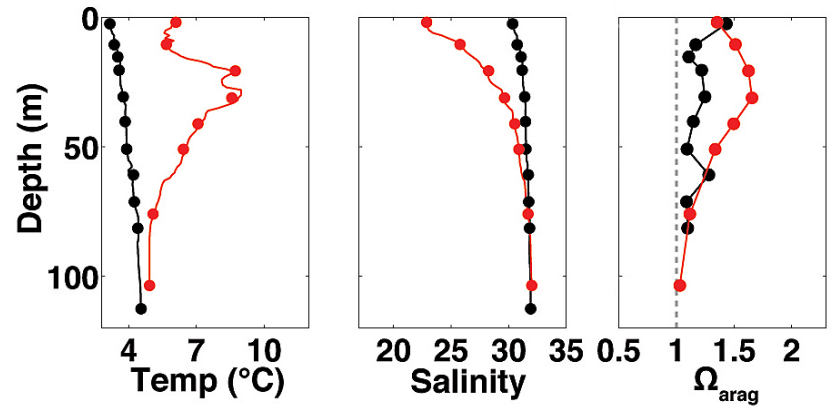

Fig. 8. Depth profiles of temperature (left; $\left.{ }^{\circ} \mathrm{C}\right)$, salinity (middle) and $\Omega_{\text {arag }}$ (right) collected in Columbia Bay (Fig. 1) during spring 2012 (black) and autumn 2012 (red). The vertical gray dashed line in the right panel denotes the $\Omega_{\text {arag }}=1$ level below which dissolution of aragonite will occur. Temperature and salinity traces are from CTD downcasts, and dots are the measurements made at the depth Niskin bottles were fired during upcasts.

magnitudes vary, however, and these features are not always directly associated with local minima in $\Omega_{\text {arag }}$ (Fig. 10). From the limited number of profiles done in PWS thus far, it is not possible to diagnose the source of chemical variability across mid-depth temperature minima, however, we can speculate that it is related to (1) year-to-year variability at the formation sites within proglacial fjords, (2) variability across potential mode water formation sites, and (3) variable connectivity between the adjacent GOA and PWS. The single May profile in a glaciated fjord prevents any kind of assessment of the first two potential sources of variability, and clearly more data are needed to address these points. However, PWS2 data does provide a hint of the variable connectivity between the adjacent GOA and PWS. For instance, calcite undersaturation was observed in the deep basin water north of K.I.P. during spring (Table 1, Figs. 3, 5). This 


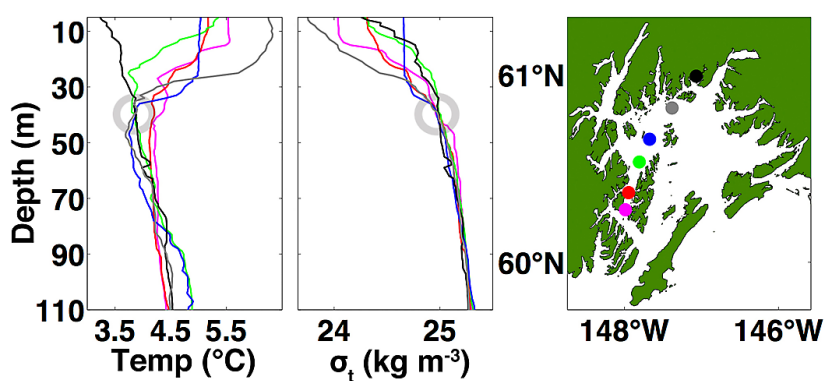

Fig. 9. Spring 2012 depth profiles of temperature $\left({ }^{\circ} \mathrm{C}\right)$ and $\sigma_{t}$ $\left(\mathrm{kg} \mathrm{m}^{-3}\right)$. The color of the profiles corresponds to the station positions shown on the map. The mode water with $T$ and $\sigma_{t}$ characteristics is identified with a gray circle in each panel.

observation has only been made once, and we speculate that this is related to the synchronicity between when our measurements were collected and when downwelling conditions abated on the shelf. Being that deep water renewal events occur during nondownwelling periods (Niebauer et al., 1994) and can flush bottom waters in as rapidly as a month (Halverson et al., 2012a), calcite undersaturation could build up during stagnant winter months in the deepest portions of PWS but be extinguished by the time our survey takes place in May given this is the time seasonal downwelling conditions are on the decline (Mathis et al., 2014b; Weingartner, 2007). Yearto-year differences in downwelling forcing on the shelf can be large (Mathis et al., 2014b), and likely determine if calcite undersaturation is observed given our set cruise schedule. Analogously, variability in the mid-depth temperature minima is likely a function of when our measurements were made relative to the conditions in PWS at the time. These temperature minima are ephemeral, lasting possibly only a few months (see Fig. 4 in Gay III and Vaughan, 2001), and have not been observed during September at PWS2 (Fig. 10).

The cumulative pulse of corrosive melt plumes from proglacial fjords in late summer/early autumn may play a large role in the decrease of average $\mathrm{CaCO}_{3}$ saturations in PWS surface water (Table 1). Surface $\Omega_{\text {arag }}$ values at PWS2 are lower in September than they are in May (Fig. 10); areal mean September $\mathrm{CaCO}_{3}$ saturations are $\sim 20 \%$ lower than those in May, and coincide with a $13 \%$ reduction in TA (Table 1). At this time, the dynamic ranges of TA and DIC increased by 85 and $67 \%$, respectively (Table 1), likely due to input of corrosive glacial melt. However, other sources of freshwater, specifically from the Copper River that flows into the GOA to the east of PWS or smaller river systems that flow directly into PWS, could also impact this pattern in TA and DIC. With the current data set, it is not possible to partition glacial melt versus other sources of freshwater. However, given the evidence described above, we expect glacial melt plays a large role in initiating the seasonal increase in $\mathrm{CaCO}_{3}$ corrosivity within PWS. Note that the lesser increase in the dynamic range of DIC relative to TA suggests that a

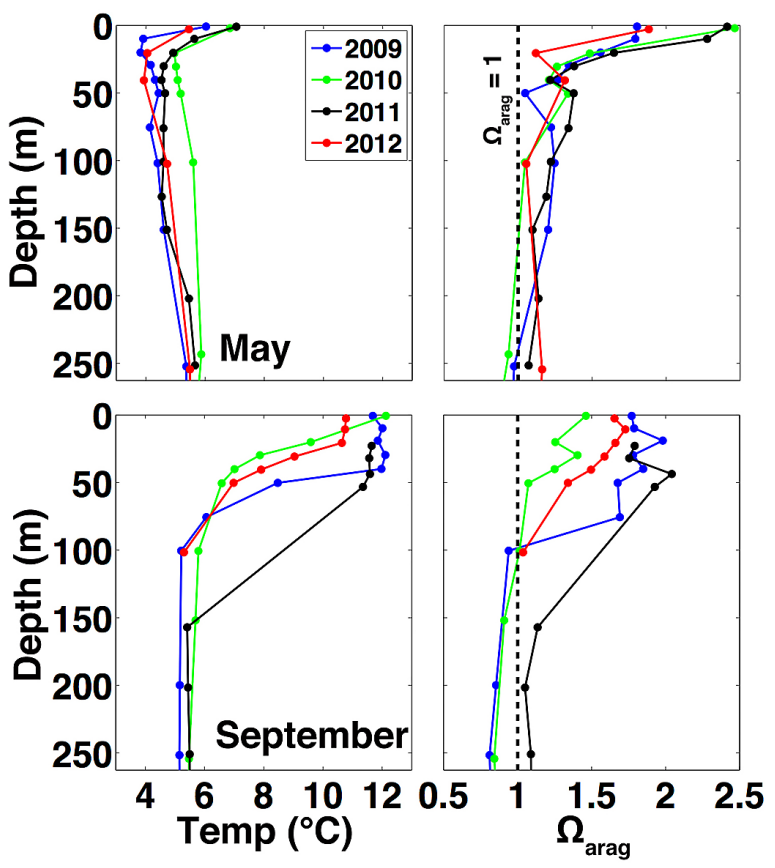

Fig. 10. Temperature $\left({ }^{\circ} \mathrm{C}\right.$; left) and $\Omega_{\text {arag }}$ (right) for K.I.P. station PWS2 (Fig. 1) for spring (top) and autumn (bottom) from 2009 through 2012. The dashed vertical lines in the right panels denote the $\Omega_{\text {arag }}=1$ level below which aragonite will dissolve.

process is adding DIC with little effect on TA, and is at play during the period of greatest observed $\mathrm{CaCO}_{3}$ corrosivity. We propose that the mechanism adding DIC is air-sea gas exchange driven by undersaturated $p \mathrm{CO}_{2}$ in corrosive glacial melt plumes.

\subsection{Air-sea exchange feedback with glacial melt}

$\mathrm{CaCO}_{3}$ corrosivity caused by the addition of glacial melt is not $\mathrm{OA}$; that is, acidification by atmospheric $\mathrm{CO}_{2}$ uptake. However, the undersaturated $p \mathrm{CO}_{2}$ and $\Omega_{\text {arag }}$ levels in glacial melt plumes can cause a feedback that further decreases $\Omega_{\text {arag }}$ levels via the addition of DIC caused by airsea $\mathrm{CO}_{2}$ exchange. This scenario may be similar for sea ice melt, which is also a source of $\mathrm{CaCO}_{3}$ corrosivity to the ocean (Yamamoto-Kawaii et al., 2009; Mathis et al., 2011b). Observations of both under and oversaturated $p \mathrm{CO}_{2}$ levels with respect to the atmosphere have been made in sea ice melt (Miller et al., 2011; Bates et al., 2009; Rysgaard et al., 2012a), and it has been suggested that a sea ice pump exists that plays a dominant role in atmospheric $\mathrm{CO}_{2}$ uptake by the Arctic Ocean (Parmentier et al., 2013; Rysgaard et al., 2007; Rysgaard et al., 2009). Undersaturated $p \mathrm{CO}_{2}$ with respect to the atmosphere in glacial melt plumes would also enhance atmospheric $\mathrm{CO}_{2}$ uptake, and the resultant increase in DIC from this exchange could further increase $\mathrm{CaCO}_{3}$ corrosivity. This change in DIC can be estimated assuming complete equilibration of the melt plume 
with the atmosphere. This estimation invokes the Revelle factor, which describes the sensitivity of $p \mathrm{CO}_{2}$ to changes in DIC (Sarmiento and Gruber, 2006; Takahashi et al., 1993). The change in DIC from air-sea gas exchange ( $\triangle \mathrm{DIC})$ can be determined by manipulating the Revelle factor definition by Sundquist et al. (1979): $\Delta \mathrm{DIC}=\Delta \mathrm{pCO}_{2} / p \mathrm{CO}_{2, \mathrm{SW}} /$ Revelle factor $\times$ DIC. $\triangle$ DIC can then be equated to a change in $\Omega_{\text {arag }}$ given the initial TA, DIC, $T$ and $S$ properties. For the case of autumn 2012 Icy Bay surface water, the air minus sea $p \mathrm{CO}_{2}\left(\Delta \mathrm{pCO}_{2}\right)$ was $85 \mu \mathrm{atm}$, seawater $p \mathrm{CO}_{2}\left(p \mathrm{CO}_{2, \mathrm{SW}}\right)$ was $295 \mu \mathrm{atm}$, DIC was $1237 \mu \mathrm{mol} \mathrm{kg}{ }^{-1}$, and the Revelle factor was 18 . This equates to a $20 \mu \mathrm{mol} \mathrm{kg} \mathrm{kg}^{-1}$ increase in DIC via atmospheric $\mathrm{CO}_{2}$ uptake, and a 0.5 unit decrease in $\Omega_{\text {arag }}$ from the observed already undersaturated conditions (Fig. 4). Assuming the glacial melt plume spans $10 \mathrm{~m}$ of the upper water column and an average September coastal ocean sea-air $\mathrm{CO}_{2}$ flux of $10 \mathrm{mmol} \mathrm{CO}_{2} \mathrm{~m}^{-2} \mathrm{~d}^{-1}$ from Evans and Mathis (2013), this change in $\Omega_{\text {arag }}$ could occur in as rapidly as 20 days.

The above example calculation can be depicted graphically for combinations of water properties mixed linearly between autumn 2012 Icy Bay surface water (TA $\left.=1285 \mu \mathrm{mol} \mathrm{kg}-1, T=6.4^{\circ} \mathrm{C}, S=18\right)$ and a approximation of TA $\left(430 \mu \mathrm{mol} \mathrm{kg}{ }^{-1}\right), T\left(0^{\circ} \mathrm{C}\right)$, and $S(0)$ properties from published data of melted glacial ice collected from the nearby land-terminating Bench Glacier (Anderson et al., 2000). The top panel in Fig. 11 shows the $p \mathrm{CO}_{2}, \Omega_{\text {arag }}$, and Revelle factor responses to mixing these two water masses linearly along the salinity gradient from 0 to 18 for different cases of TA/DIC ratio ranging from 1.15 to 1.00. This range of TA / DIC ratios brackets the highest and lowest values observed in the PWS data set (Table 1), and produces an envelope of trajectories for $p \mathrm{CO}_{2}, \Omega_{\mathrm{arag}}$, and Revelle factor values that result from mixing across the continuum between Bench Glacier and Icy Bay waters. This calculation shows that the TA/DIC ratio of Icy Bay water sets whether coincidently undersaturated $p \mathrm{CO}_{2}$ and $\Omega_{\text {arag }}$ will be observed. When the TA / DIC ratio of Icy Bay water is high (e.g., 1.15), undersaturation of $p \mathrm{CO}_{2}$ and supersaturation of aragonite occurs at higher salinities. When the TA/DIC ratio of Icy Bay water is low (e.g., 1.00), supersaturation of $p \mathrm{CO}_{2}$ coincides with undersaturations of $\Omega_{\text {arag }}$ at higher salinities. Across the mixing continuum, all potential mixing combinations at the low-salinity end indicate that undersaturations of $p \mathrm{CO}_{2}$ and $\Omega_{\text {arag }}$ will co-occur. This calculation also shows that the Revelle factor is maximized for glacial plumes in Icy Bay waters with low TA / DIC ratios. The uptake of atmospheric $\mathrm{CO}_{2}$ in these conditions could exacerbate existing $\Omega_{\text {arag }}$ undersaturations.

The lower panel in Fig. 11 illustrates the potential change in $\Omega_{\text {arag }}\left(\Delta \Omega_{\text {arag }}\right)$ that would ensue if surface water $p \mathrm{CO}_{2}$ equilibrated with the atmosphere, given the $p \mathrm{CO}_{2}$, DIC and Revelle factor conditions from the upper panel. $\Delta \Omega_{\text {arag }}$ will have no change or be positive only when surface water $p \mathrm{CO}_{2}$ is near or above saturation with the atmosphere. By

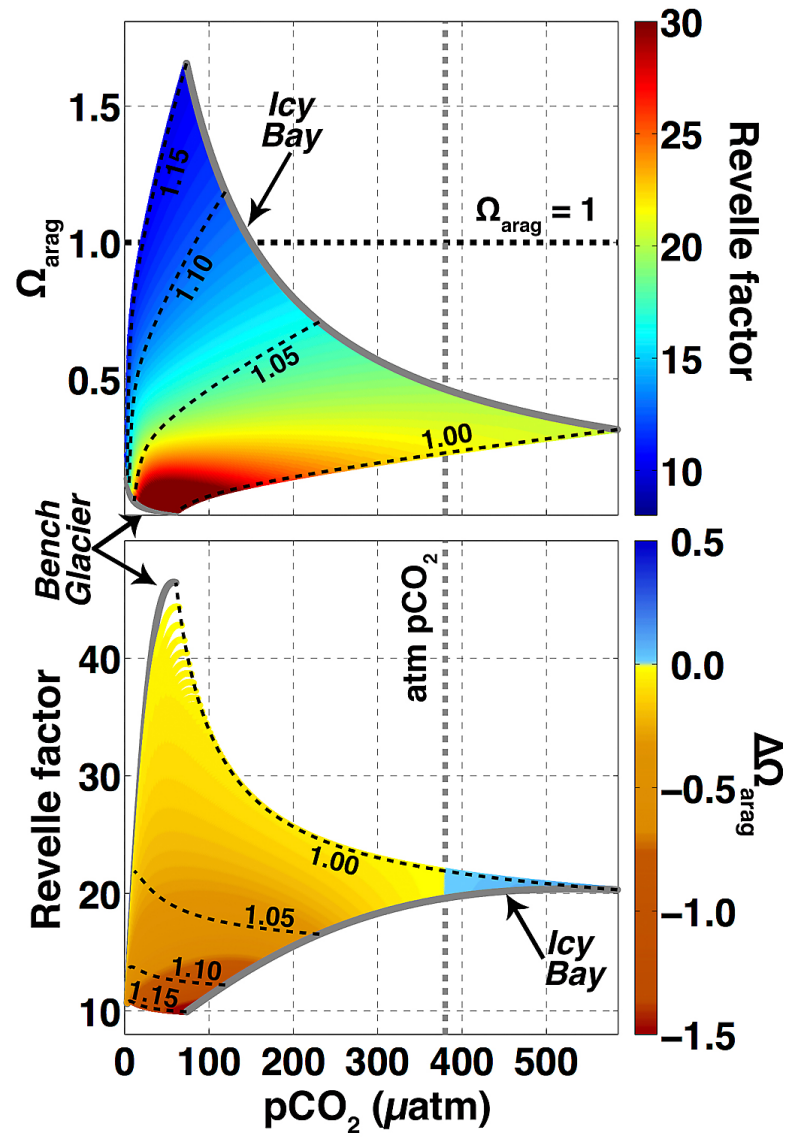

Fig. 11. A representation of the positive feedback between the addition of direct glacial melt and the uptake of atmospheric $\mathrm{CO}_{2}$

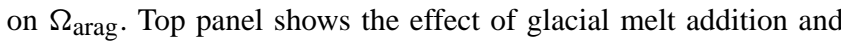
the TA/DIC ratio (1.00 to 1.15 ) on $\Omega_{\text {arag }}, p \mathrm{CO}_{2}$ ( $\mu$ atm) and the Revelle factor for water masses mixed linearly between Icy Bay TA $\left(1250 \mu \mathrm{mol} \mathrm{kg}{ }^{-1}\right), S(18)$ and $T\left(5^{\circ} \mathrm{C}\right)$ and Bench Glacier TA $(430 \mu \mathrm{mol} \mathrm{kg}-1), S(0)$ and $T\left(0^{\circ} \mathrm{C}\right)$ at $1 \mathrm{~atm}$. Bench Glacier TA is from Anderson et al. (2000). Icy Bay and Bench Glacier data over the range of TA / DIC ratios are marked with gray lines. The black horizontal dashed line is the $\Omega_{\text {arag }}=1$ level below which dissolution of aragonite will occur. The gray vertical dashed line is the September 2012 atmospheric $p \mathrm{CO}_{2}$ in Prince William Sound estimated following Evans and Mathis $(2013 ; 380 \mu \mathrm{atm})$. Trajectories of constant TA/DIC show different scenarios of increasing $\Omega_{\mathrm{arag}}$ and $p \mathrm{CO}_{2}$, and decreasing Revelle factors. The lower panel shows the change in $\Omega_{\text {arag }}\left(\Delta \Omega_{\text {arag }}\right.$ ) that would result from the complete equilibration of the melt plumes with the atmosphere at the $p \mathrm{CO}_{2}$, DIC and Revelle factor conditions represented by the trajectories shown in the top panel (i.e., lines of TA/DIC are those shown in the top panel and not adjusted for air-sea gas exchange). As such, $\Delta \Omega_{\text {arag }}$ is negative in waters gaining DIC and being acidified, and positive is waters losing DIC via air-sea gas exchange. The most negative $\Delta \Omega_{\text {arag }}$ values are in buffered plume water (Revelle factor $<15$ ) with high TA/DIC ratios due to $p \mathrm{CO}_{2}$ levels well below saturation with the atmosphere and saturated $\Omega_{\text {arag values. Weakly }}$

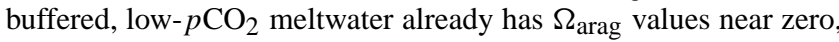
so $\mathrm{CO}_{2}$ uptake from the atmosphere will have little effect. 
contrast, weakly buffered, low- $p \mathrm{CO}_{2}$ meltwater already has $\Omega_{\text {arag }}$ values near zero, $\mathrm{CO}_{2}$ uptake from the atmosphere will have little effect and $\Delta \Omega_{\text {arag }}$ is also negligible. In all other cases, acidification by atmospheric $\mathrm{CO}_{2}$ uptake will intensify $\mathrm{CaCO}_{3}$ corrosivity in glacial melt plumes. These calculations only take into account air-sea $\mathrm{CO}_{2}$ exchange, although the time rate of change for $p \mathrm{CO}_{2}$ and $\Omega$ are both also dependent on warming, mixing and biological processes. True trajectories of the evolution of $p \mathrm{CO}_{2}$ and $\Omega$ in glacial melt plumes fall somewhere within the envelopes depicted in Fig. 11. Given the wide range of variability, it is essential to resolve these trajectories in order to make robust predictions of the downstream impact of glacial melt addition.

Corrosive melt plumes increase in corrosivity via air-sea gas exchange, and will impart their corrosivity on adjacent coastal water through mixing. This increase might be slightly offset if the buoyant melt bloom acted as a nutrient source to the surface via turbulent mixing during its formation. A resultant phytoplankton bloom could act to decrease the corrosivity of the upper water column via DIC draw down, albeit it is unclear whether this would balance the addition of DIC from air-sea gas exchange. Monthly climatologies of satellite chlorophyll from the Moderate Resolution Imaging Spectroradiometer (MODIS) suggest that phytoplankton abundance (using chlorophyll as a proxy) is generally low throughout most of the year in the portion of the sound populated by tidewater glaciers (Figs. 1, 12). Our data from Icy Bay show no evidence of an upwelling source of nutrients (Fig. 6), and we argue that the interaction between glacial melt plumes and air-sea $\mathrm{CO}_{2}$ exchange is the likely candidate to explain the disparity between changes in TA and DIC dynamic ranges between May and September and the seasonal reduction of $\Omega$ in PWS surface waters (Table 1). Further study should evaluate the evolution of the coupled roles of glacial melt addition, alternate sources of freshwater, primary productivity, and atmospheric $\mathrm{CO}_{2}$ uptake in driving this change in $\mathrm{CaCO}_{3}$ corrosivity. The data we have presented here serve as a baseline for our understanding of the carbonate system in PWS, and indicates the important role glacial melt has in this system. We anticipate the influence of glacial melt on the PWS carbonate system also affects the adjacent continental margin.

\subsection{Transmitting corrosive PWS water to the continental shelf}

$\mathrm{CaCO}_{3}$ corrosivity from glacial melt impacts the upper $50 \mathrm{~m}$ of the water column of PWS in two ways: (1) as mode waters with distinct chemical signals, and (2) as surface plumes of glacial melt. These seasonally distinct signals imply a transition from a refugium from $\mathrm{CaCO}_{3}$ corrosivity for surface-dwelling organisms in May to a more corrosive surface environment in September. The opposite would be the case for sub-surface waters influenced by mode waters formed in proglacial fjords, with corrosivity there reduced in September as opposed to May. The downstream extent of mode waters emanating from proglacial fjords is uncertain, and likely impacts a narrow range of the water column over relatively short distances. However, ribbons of corrosive mode water extending from proglacial fjords can be sources of the large mid-depth variability, as observed by Evans et al. (2013b) on the GOA continental margin, with potential consequences for vertical migrating organisms in the water column. Contrary to this local impact, the seasonal increase of $\mathrm{CaCO}_{3}$ corrosivity in the PWS surface layer may have farther-reaching effects. During the nondownwelling period of the year, the "flow-through" scenario seen in PWS is far less distinct (Niebauer et al., 1994; Halverson et al., 2012a) due to the constricted nature of this inland sea combined with reduced downwelling-favorable winds, and concomitant with this is the seasonal increase in $\mathrm{CaCO}_{3}$ corrosivity. When downwelling-favorable winds increase in September, corrosive surface water that has built up in PWS would be rapidly evacuated to the continental shelf. This pulse of $\mathrm{CaCO}_{3}$ corrosivity would become integrated into the poleward, alongshore-flowing Alaska Coastal Current, and impact ecosystems downstream. Cruise data collected thus far have not resolved this potential pulse of corrosivity to the continental margin from the PWS. This is a critical and currently undiagnosed link between PWS and the GOA that must be addressed by future research.

\subsection{Predicting corrosivity on glacially influenced margins}

A critical result applicable to any coastal area impacted by glacial melt is that $\mathrm{CaCO}_{3}$ corrosivity is poorly reflected by $p \mathrm{CO}_{2}$ or $\mathrm{pH}_{\mathrm{T}}$ alone, indicating that either one of these carbonate parameters in isolation would fail to track corrosive conditions in these settings. This is not the case for the manifestation of $\mathrm{CaCO}_{3}$ corrosivity in coastal upwelling regions (Feely et al., 2008; Harris et al., 2013b) or in areas impacted by rivers (Salisbury et al., 2008; Cai et al., 2011; Evans et al., 2013a; Feely et al., 2012) that experience high $p \mathrm{CO}_{2}$. This realization is essential for the establishment of robust monitoring efforts targeting OA in proglacial coastal settings. The approach of Mathis et al. (2014c) to employ empirical relationships between $p \mathrm{CO}_{2}$ and $\Omega_{\text {arag }}$ in order to track $\mathrm{CaCO}_{3}$ corrosivity in bottom waters on the Bering Sea shelf would fall short in this setting because of the decoupling of these parameters in regions impacted by glacial melt. Although untested in proglacial fjords, the multiple linear regressions (MLR) developed by Evans et al. (2013b) should fare better as those predict both TA and DIC, thereby accounting for the nonlinearity of the carbonate system that provokes the variability in $\Omega$ at low $p \mathrm{CO}_{2}$ levels (Figs. 3, 5). However, we expect large error in the predictions using those equations because the relationship between $\mathrm{NO}_{3}^{-}$and DIC in glacial meltwater is uncertain, and the MLR's used by Evans et al. (2013b) are heavily based on $\mathrm{NO}_{3}^{-}$. Only the direct 


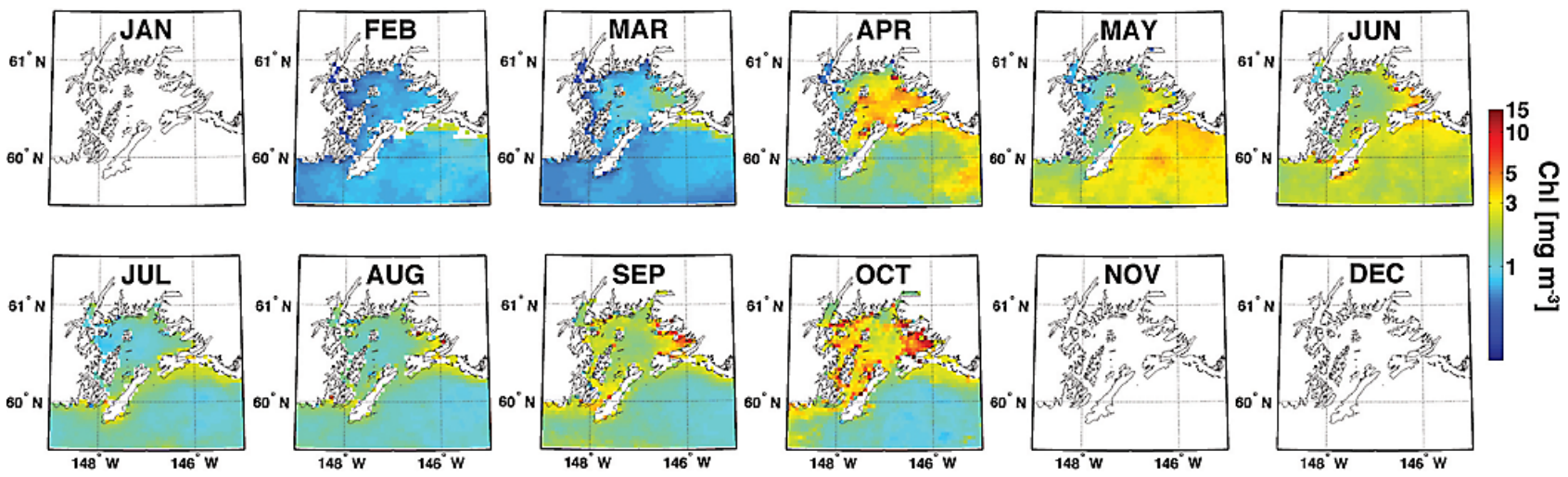

Fig. 12. Monthly climatology of MODIS chlorophyll $\left(\mathrm{mg} \mathrm{m}^{-3}\right)$ for Prince William Sound. November, December and January lack data due to persistent cloud cover during those months. Monthly climatologies are provided by the National Aeronautics and Space Administration (http://oceandata.sci.gsfc.nasa.gov/MODISA/Mapped/Monthly_Climatology/4km/chlor/).

measurement of two carbonate parameters will allow $\Omega_{\text {arag }}$ to be accurately quantified in settings where glacial melt plumes are encountered.

\section{Summary}

We have presented a growing data set of carbonate system measurements collected within PWS, a semienclosed inland sea on the south-central coast of Alaska. These data revealed that conditions corrosive to $\mathrm{CaCO}_{3}$ evolve through the influence of glacial discharge in a seasonally dependent manner: as near-corrosive mode water emanating for proglacial fjords, and as glacial melt plumes. $\mathrm{CaCO}_{3}$ corrosivity was most intense in glacial melt plumes proximal to the terminal face of the Chenega tidewater glacier in Icy Bay. This plume water was undersaturated with respect to both aragonite (and nearly so for calcite) and atmospheric $p \mathrm{CO}_{2}$. Simultaneous undersaturation of $\Omega_{\text {arag }}$ and $p \mathrm{CO}_{2}$ sets up the condition whereby air-sea gas exchange can exacerbate $\mathrm{CaCO}_{3}$ corrosivity by increasing DIC. This situation is unique to environments influenced by glacial melt plumes, and demonstrates that $p \mathrm{CO}_{2}$ or $\mathrm{pH}_{\mathrm{T}}$ alone would fail to capture manifestations of $\mathrm{CaCO}_{3}$ corrosivity in these regions. We speculate that the impact of glacial melt plumes acts in concert with atmospheric $\mathrm{CO}_{2}$ uptake to reduce average $\Omega$ during September relative to May when surface melt plumes are nonexistent. This is a seasonally modulated process that is likely terminated at the start of downwelling season when PWS functions in more of a "flow through" manner, evacuating a pulse of corrosive surface water to the adjacent GOA continental margin. The addition of glacial melt to PWS, combined with its semiconfined circulation pattern during the melt season, make it susceptible to significantly amplified corrosivity due to increasing atmospheric $\mathrm{CO}_{2}$. The link between the addition of corrosive glacial melt and air-sea gas exchange should be further studied as this potentially plays a signif- icant role in shaping ecosystems both within PWS and in areas downstream along the coast of Alaska that would be affected by the autumn release of corrosive surface waters.

Acknowledgements. We are grateful to Capt. Billy Pepper and the crew of US Fish and Wildlife Service R/V Tiglax for their help and support of our work in Prince William Sound. We express gratitude toward Natalie Monacci, Dan Naber, Stacey Reisdorph and Kristen Shake for their help with data collection and sample processing, and Molly McCammon for her continued support of ocean acidification research in Alaska. We are grateful for the constructive comments from two anonymous reviewers. This work was funded by the Alaska Ocean Observing System under NOAA awards A08NOS4730406 and NA11NOS0120020, the National Science Foundation (PLR-1107997) and the NOAA Ocean Acidification Program.

Edited by: M. Dai

\section{References}

Anderson, S. P., Drever, J. I., Frost, C. D., and Holder, P.: Chemical weathering in the foreland of a retreating glacier, Geochim Cosmochim. Ac., 64, 1173-1189, 2000.

Arendt, A., Echelmeyer, K. A., Harrison, W., Lingle, C., Zirnheld, S., Valentine, V., Ritchie, B., and Druckenmiller, M.: Updated estimates of glacier volume changes in the western Chugach Mountains, Alaska, and a comparison of regional extrapolation methods, J. Geophys. Res., 111, F03019,, doi:10.1029/2005JF000436, 2006.

Arendt, A. A., Echelmeyer, K. A., Harrison, W. D., Lingle, C. S., and Valentine, V. B.: Rapid Wastage of Alaska Glaciers and Their Contribution to Rising Sea Level, Science, 297, 382-386, 2002.

Azetsu-Scott, K., Clarke, A., Falkner, K., Hamilton, J., Jones, E. P., Lee, C., Petrie, B., Prinsenberg, S., Starr, M., and Yeats, P.: Calcium carbonate saturation states in the waters of the Canadian Arctic Archipelago and the Labrador Sea, J. Geophys. Res., 115, C11021, doi:10.1029/2009JC005917, 2010. 
Barton, A., Hales, B., Waldbusser, G., Langdon, C., and Feely, R. A.: The Pacific oyster, Crassostrea gigas, shows negative correlation to naturally elevated carbon dioxide levels: Implications for near-term ocean acidification effects, Limnol. Oceanogr., 57, 698-710, 2012.

Bates, N. R., Mathis, J. T., and Cooper, L. W.: Ocean acidification and biologically induced seasonality of carbonate mineral saturation states in the western Arctic Ocean, J. Geophys. Res., 114, C11007, doi:10.1029/2008JC004862, 2009.

Berthier, E., Schiefer, E., Clarke, G. K. C., Menounos, B., and Rémy, F.: Contribution of Alaskan glaciers to sea-level rise derived from satellite imagery, Nat. Geosci., 3, 92-95, doi:10.1038/NGE0737, 2010.

Bhatia, M. P., Kujawinski, E. B., Das, S. B., Breier, C. F., Henderson, P. B., and Charette, M. A.: Greenland meltwater as a significant and potentially bioavailable source of iron to the ocean, Nat. Geosci., 6, 274-278, doi:10.1038/ngeo1746, 2013.

Brown, G. H.: Glacier meltwater hydrochemistry, Appl. Geochem., 17, 855-883, 2002.

Bryne, R. H., Mecking, S., Feely, R. A., and Liu, X.: Direct observations of basin-wide acidification on the North Pacific Ocean, Geophys. Res. Lett., 37, L02601, doi:10.1029/2009GL040999, 2010.

Cai, W.-J., Hu, X., Huang, W.-J., Murrell, M. C., Lehrter, J. C., Lohrenz, S. E., Chou, W.-C., Zhai, W., Hollibaugh, J. T., Wang, Y., Zhao, P., Guo, X., Gundersen, K., Dai, M., and Gong, G.-C.: Acidification of subsurface coastal waters enhanced by eutrophication, Nat. Geosci., 4, 766-770, 2011.

Caldeira, K. and Wickett, M. E.: Anthropogenic carbon and ocean pH, Nature, 425, 365, doi:10.1038/425365a, 2003.

Chierici, M. and Fransson, A.: Calcium carbonate saturation in the surface water of the Arctic Ocean: undersaturation in freshwater influenced shelves, Biogeosciences, 6, 2421-2431, doi:10.5194/bg-6-2421-2009, 2009.

Cooley, S. R. and Doney, S. C.: Anticipating ocean acidification's economic consequences for commerical fisheries, Environ. Res. Lett., 4, 1-8, doi:10.1088/1748-9326/4/2/024007, 2009.

Dickson, A. G.: The carbon dioxide system in seawater: equilibrium chemistry and measurements, in: Guide to best practices for ocean acidification research and data reporting, edited by: Riebesell, U., Fabry, V. J., Hansson, L., and Gattuso, J.-P., Publications Office of the European Union, Luxembourg, 260, 2010.

Dierssen, H., Smith, R. C., and Vernet, M.: Glacial meltwater dynamics in coastal waters west of the Antarctic peninsula, P. Natl. Acad. Sci. USA, 99, 1790-1795, 2002.

Doney, S. C., Fabry, V. J., Feely, R. A., and Kleypas, J. A.: Ocean Acidification: The Other $\mathrm{CO}_{2}$ Problem, Annu. Rev. Mar. Sci., 1, 169-192, 2009.

Dore, J. E., Lukas, R., Sadler, D. W., Church, M. J., and Karl, D. M.: Physical and biogeochemical modulation of ocean acidification in the central North Pacific, P. Natl. Acad. Sci. USA, 106, 1223512240, 2009.

Evans, W. and Mathis, J. T.: The Gulf of Alaska coastal ocean as an atmospheric $\mathrm{CO}_{2}$ sink, Cont. Shelf Res., 65, 52-63, 2013.

Evans, W., Hales, B., and Strutton, P. G.: $p \mathrm{CO}_{2}$ distributions and air-water $\mathrm{CO}_{2}$ fluxes in the Columbia River estuary, Estuar. Coast. Shelf S., 117, 260-272, doi:10.1016/j.ecss.2012.1012.1003, 2013a.
Evans, W., Mathis, J. T., Winsor, P., Whitledge, T., and Statscewich, H.: A regression modeling approach for studying carbonate saturation states on the northern Gulf of Alaska shelf, J. Geophys. Res., 118, 476-489, doi:10.1029/2012JC008246, 2013b.

Fabry, V. J., Seibel, B. A., Feely, R. A., and Orr, J. C.: Impacts of ocean acidification on marine fauna and ecosystem processes, ICES J. Mar. Sci., 65, 414-432, 2008.

Feely, R. A., Sabine, C. L., Lee, K., Berelson, W., Kleypas, J., Fabry, V. J., and Millero, F. J.: Impact of Anthropogenic $\mathrm{CO}_{2}$ on the $\mathrm{CaCO}_{3}$ System in the Oceans, Science, 305, 362-366, 2004.

Feely, R. A., Sabine, C. L., Hernandez-Ayon, M., Ianson, D., and Hales, B.: Evidence for Upwelling of Corrosive "Acidified" Water onto the Continental Shelf, Science, 320, 1490-1492, 2008.

Feely, R. A., Doney, S. C., and Cooley, S. R.: Ocean Acidification: Present Conditions and Future Changes in a High- $\mathrm{CO}_{2}$ World, Oceanography, 22, 36-47, 2009.

Feely, R. A., Alin, S. R., Newton, J., Sabine, C. L., Warner, M., Devol, A., Krembs, C., and Maloy, C.: The combined effects of ocean acidification, mixing, and respiration on $\mathrm{pH}$ and carbonate saturation in an urbanized estuary, Estuar. Coast. Shelf S., 88, 442-449, 2010.

Feely, R. A., Klinger, T., Newton, J. A., and Chadset, M.: Scientific Summary of Ocean Acidification in Washington State Marine Waters, 2012.

García, H. E. and Gordon, L. I.: Oxygen solubility in seawater: Better fitting equations, Limnol. Oceanogr., 37, 1301-1312, 1992.

Gardner, A. S., Moholdt, G., Cogley, J. G., Wouters, B., Arendt, A. A., Wahr, J., Berthier, E., Hock, R., Pfeffer, W. T., Kaser, G., Ligtenberg, S. R. M., Bolch, T., Sharp, M. J., Hagen, J. O., van den Broeke, M. R., and Paul, F.: A Reconciled Estimate of Glacier Contributions to Sea Level Rise: 2003 to 2009, Science, 340, 852-857, 2013.

Gay III, S. M. and Vaughan, S. L.: Seasonal hydrography and tidal currents of bays and fjords in Prince William Sound, Alaska, Fish. Oceanogr., 10, 159-193, 2001.

Halverson, M. J., Bélanger, C., and Gay III, S. M.: Seasonal transport variations in the straits connecting Prince William Sound to the Gulf of Alaska, Cont. Shelf Res., 63, S63-S78, 2012a.

Halverson, M. J., Ohlmann, J. C., Johnson, M. A., and Pegau, W. S.: Disruption of a cyclonic eddy circulation by wind stress in Prince William Sound, Alaska, Cont. Shelf Res., 63, S13-S25, 2012b.

Harris, K. E., DeGrandpre, M. D., and Hales, B.: Aragonite saturation state dynamics in a coastal upwelling zone, Geophys. Res. Lett., 40, 2720-2725, doi:10.1002/grl.50460, 2013a.

Harris, K. E., Degrandpre, M. D., and Hales, B.: Aragonite saturation state dynamics in a coastal upwelling zone, Geophys. Res. Lett., 40, 2720-2725, doi:10.1002/grl.50460, 2013 b.

Hood, E., Fellman, J., Spencer, R. G. M., Hernes, P. J., Edwards, R., D'Amore, D., and Scott, D.: Glaciers as a source of ancient and labile organic matter to the marine environment, Nature, 464, 1044-1047, 2009.

Langdon, C.: Determination of Dissolved Oxygen in Seawater by Winkler Titration using the Amperometric Technique, IOC/IOCCP, Paris, 2010.

Larsen, C. F., Motyka, R. J., Arendt, A. A., Echelmeyer, K. A., and Geissler, P. E.: Glacier changes in southeast Alaska and northwest British Columbia and contribution to sea level rise, J. Geophys. Res., 112, F01007, doi:10.1029/2006JF000586, 2007. 
Leinweber, A. and Gruber, N.: Variability and trends of ocean acidification in the Southern California Current System: A time series from Santa Monica Bay, J. Geophys. Res., 118, 3622-3633, doi:10.1002/jgrc.20259, 2013.

Lueker, T. J., Dickson, A. G., and Keeling, R. F.: Ocean $p \mathrm{CO}_{2}$ calculated from dissolved inorganic carbon, alkalinity, and equations for $K_{1}$ and $K_{2}$ : validation based on laboratory measurements of $\mathrm{CO}_{2}$ in gas and seawater at equilibrium, Mar. Chem., 70, 105-119, 2000.

Mathis, J. T., Cross, J. N., and Bates, N. R.: The role of ocean acidification in systemic carbonate mineral suppression in the Bering Sea, Geophys. Res. Lett., 38, L19602, doi:10.1029/2011GL048884, 2011a.

Mathis, J. T., Cross, J. N., and Bates, N. R.: Coupling primary production and terrestrial runoff to ocean acidification and carbonate mineral suppression in the eastern Bering Sea, J. Geophys. Res., 116, C02030, doi:10.1029/2010JC006453, 2011 b.

Mathis, J. T., Cooley, S. R., Lucey, N., Hauri, C., Ekstrom, J., Hurst, T., Colt, S., Evans, W., Cross, J. N., and Feely, R. A.: Ocean Acidification Risk Assessment for Alaska's Fishery Sector, Progr. Oceanogr., submitted, 2014a.

Mathis, J. T., Evans, W., Cross, J. N., and Stockwell, D. A.: Physical and Biogeochemical Controllers of Ocean Acidification in the Northern Gulf of Alaska, J. Geophys. Res., in preparation, 2014b.

Mathis, J. T., Cross, J. N., Monacci, N., Feely, R. A., and Stabeno, P. $\mathrm{J}$. : Evidence of prolonged aragonite undersaturations in the bottom waters of the southern Bering Sea shelf from autonomous sensors, Deep-Sea Res. II, in press, 2014c.

Miller, L. A., Papakyriakou, T. N., Collins, R. E., Deming, J. W., Ehn, J. K., Macdonald, R. W., Mucci, A., Owens, O., Raudsepp, M., and Sutherland, N.: Carbon dynamics in sea ice: A winter flux time series, J. Geophys. Res., 116, C02028, doi:10.1029/2009JC006058, 2011.

Millero, F. J.: The Marine Inorganic Carbon Cycle, Chem. Rev., 107, 308-341, 2007.

Mortensen, J., Bendtsen, J., Motyka, R. J., Lennert, K., Truffer, M., Fahnestock, M., and Rysgaard, S.: On the seasonal freshwater stratification in the proximity of fast-flowing tidewater outlet glaciers in a sub-Arctic sill fjord, J. Geophys. Res., 118, 13821395, 2013.

Motyka, R. J., Hunter, L., Echelmeyer, K. A., and Conner, C.: Submarine melting at the terminus of a temperate tidewater glacier, LeConte Glacier, Alaska, U.S.A., Ann. Glaciol., 36, 5765, 2003.

Musgrave, D. L., Halverson, M. J., and Pegau, W. S.: Seasonal surface circulation, temperature, and salinity in Prince William Sound, Alaska, Cont. Shelf Res., 53, 20-29, 2013.

Neal, E. G., Hood, E., and Smikrud, K.: Contribution of glacier runoff to freshwater discharge into the Gulf of Alaska, Geophys. Res. Lett., 37, L06404, doi:10.1029/2010GL042385, 2010.

Niebauer, H. J., Royer, T. C., and Weingartner, T. J.: Circulation of Prince William Sound, Alaska, J. Geophys. Res., 99, 1411314126, 1994.

Orr, J. C., Fabry, V. J., Aumont, O., Bopp, L., Doney, S. C., Feely, R. A., Gnanadesikan, A., Gruber, N., Ishida, A., Joos, F., Key, R. M., Lindsay, K., Maier-Reimer, E., Matear, R., Monfray, P., Mouchet, A., Najjar, R. G., Plattner, G.-K., Rodgers, K. B., Sabine, C. L., Sarmiento, J. L., Schlitzer, R., Slater, R. D., Totterdell, I. J., Weirig, M.-F., Yamanaka, Y., and Yool, A.: Anthropogenic ocean acidification over the twenty-first century and its impact on calcifying organisms, Nature, 437, 681-686, 2005.

Parmentier, F.-J. W., Christensen, T. R., Sørensen, L. L., Rysgaard, S., McGuire, A. D., Miller, P. A., and Walker, D. A.: The impact of lower sea-ice extent on Arctic greenhouse-gas exchange, Nat. Clim. Change, 3, 195-202, 2013.

Pickard, G. L.: Some Oceanographic Characteristics of the Larger Inlets of Southeast Alaska, J. Fish. Res. Board Can., 24, 14751506, 1967.

Post, A., O’Neel, S., Motyka, R. J., and Streveler, G.: A Complex Relationship Between Calving Glaciers and Climate, EOS T. Am. Geophys. Un., 92, 305-306, 2011.

Raven, J., Caldeira, K., Elderfield, H., Hoegh-Guldberg, O., Liss, P. S., Riebesell, U., Shepherd, J., Turley, C., Watson, A. J., Heap, R., Banes, R., and Quinn, R.: Ocean acidification due to increasing atmospheric carbon dioxide, The Royal Society, 2005.

Ritchie, J. B., Lingle, C. S., Motyka, R. J., and Truffer, M.: Seasonal fluctuations in the advance of a tidewater glacier and potential causes: Hubbard Glacier, Alaska, USA, J. Glaciol., 54, 401-411, 2008.

Rysgaard, S., Glud, R. N., Sejr, M. K., Bendtsen, J., and Christensen, P. B.: Inorganic carbon transport during sea ice growth and decay: A carbon pump in polar seas, J. Geophys. Res., 112, C03016, doi:10.1029/2006JC003572, 2007.

Rysgaard, S., Bendtsen, J., Pedersen, L. T., Ramløv, H., and Glud, R. N.: Increased $\mathrm{CO}_{2}$ uptake due to sea ice growth and decay in the Nordic Seas, J. Geophys. Res., 114, C09011, doi:10.1029/2008JC005088, 2009.

Rysgaard, S., Glud, R. N., Lennert, K., Cooper, M., Halden, N., Leakey, R. J. G., Hawthorne, F. C., and Barber, D.: Ikaite crystals in melting sea ice - implications for $p \mathrm{CO}_{2}$ and $\mathrm{pH}$ levels in Arctic surface waters, The Cryosphere, 6, 901-908, doi:10.5194/tc6-901-2012, 2012a.

Rysgaard, S., Mortensen, J., Juul-Pedersen, T., Sørensen, L. L., Lennert, K., Søgaard, D. H., Arendt, K. E., Blicher, M. E., Sejr, M. K., and Bendtsen, J.: High air-sea $\mathrm{CO}_{2}$ uptake rates in nearshore and shelf areas of Southern Greenland: Temporal and spatial variability, Mar. Chem., 128-129, 26-33, 2012 b.

Salisbury, J., Green, M., Hunt, C., and Campbell, J.: Coastal Acidification by Rivers: A Threat to Shellfish?, EOS T. Am. Geophys. Un., 89, 513-514, 2008.

Sarmiento, J. L. and Gruber, N.: Ocean Biogeochemical Dynamics, Princeton University Press, Princeton, 2006.

Sejr, M. K., Krause-Jensen, D., Rysgaard, S., Sørensen, L. L., Christensen, P. B., and Glud, R. N.: Air-sea flux of $\mathrm{CO}_{2}$ in arctic coastal waters influenced by glacial melt water and sea ice, Tellus B, 63, 815-822, 2011.

Shadwick, E. H., Rintoul, S. R., Tilbrook, B., Williams, G. D., Young, N., Fraser, A. D., Marchant, H., Smith, J., and Tamura, T.: Glacier tongue calving reduced dense water formation and enhanced carbon uptake, Geophys. Res. Lett., 40, 904-909, doi:10.1002/grl.50178, 2013.

Sundquist, E. T., Plummer, L. N., and Wigley, T. M. L.: Carbon Dioxide in the Ocean Surface: The Homogeneous Buffer Factor, Science, 204, 1203-1205, 1979.

Takahashi, T., Olafsson, J., Goddard, J. G., Chipman, D. W., and Sutherland, S. C.: Seasonal Variation of $\mathrm{CO}_{2}$ and Nutrients in the High-Latitude Surface Oceans: a Comparative Study, Global 
Biogeochem. Cy., 7, 843-878, doi:10.1029/1093GB02263, 1993.

Tank, S. E., Raymond, P. A., Striegl, R. G., McClelland, J. W., Holmes, R. M., Fiske, G. J., and Peterson, B. J.: A land-to-ocean perspective on the magnitude, source and implication of DIC flux from major Arctic rivers to the Arctic Ocean, Global Biogeochem. Cy., 26, GB4018, doi:10.1029/2011GB004192, 2012. van Heuven, S., Pierrot, D., Rae, J. W. B., Lewis, E., and Wallace, D. W. R.: MATLAB Program Developed for $\mathrm{CO}_{2}$ System Calculations Department of Energy, Oak Ridge, Tennessee, 2011.

Vaughan, S. L., Mooers, C. N. K., and Gay III, S. M.: Physical variability in Prince William Sound during the SEA Study (199498), Fish. Oceanogr., 10, 58-80, 2001.

Walters, R. A., Josberger, E. G., and Driedger, C. L.: Columbia Bay, Alaska: an "Upside Down" Estuary, Estuar. Coast. Shelf S., 26, 607-617, 1988.
Weingartner, T.: The Physical Environment of the Gulf of Alaska, in: Long-term Ecological Change in the Northern Gulf of Alaska, edited by: Spies, R. B., Elsevier, Oxford, 589, 2007.

Whitledge, T., Malloy, S. C., Patton, C. J., and Wirick, C. D.: Automated nutrient analyses in seawater, Brookhaven National Laboratory Technical Report BNL 51398, edited by: Laboratory, B. N., National Technical Information Service, Upton, New York, 1981.

Yamamoto-Kawaii, M., McLaughlin, F. A., Carmack, E. C., Nishino, S., and Shimada, K.: Aragonite Undersaturation in the Arctic Ocean: Effects of Ocean Acidification and Sea Ice Melt, Science, 326, 1098-1100, doi:10.1126/science.1174190, 2009.

Yamamoto-Kawaii, M., McLaughlin, F. A., and Carmack, E.: Ocean acidification in the three oceans surrounding northern North America, J. Geophys. Res., 118, 6274-6284, doi:10.1002/2013JC009157, 2013. 